INEEL/EXT-99-01302

December 1999

\title{
Light Duty Utility Arm Deployment in Tank WM-188
}

M. Patterson

B ECHTEL B WXT I DAHO, L LC 


\title{
Light Duty Utility Arm Deployment in Tank WM-188
}

\author{
M. Patterson
}

Published December 1999

Idaho National Engineering and Environmental Laboratory Idaho Falls, Idaho 83415

\author{
Prepared for the \\ U.S. Department of Energy \\ Assistant Secretary for \\ Environmental Management \\ Under DOE Idaho Operations Office \\ Contract DE-AC07-99ID13727
}




\section{SUMMARY}

The Light Duty Utility Arm (LDUA) was successfully deployed in Tank WM-188 during February and March of 1999. Some equipment problems were identified, but most were indicative of any first time activity. Deployment during cold weather imposed additional equipment risks, but in general, equipment response to the winter conditions was better than expected. The LDUA was subsequently removed from the Idaho Nuclear Technology and Engineering Center (INTEC) tank farm and stored for future deployments.

Three end effectors were demonstrated during the deployment. All performed as expected, although the limited resolution of the Alternating Current Field Measurement end effector cannot absolutely confirm tank integrity, which is necessary for future tank inspections. Four heel samples were taken with the sampler end effector and a broad spectrum of analyses were performed. A detailed inspection of the tank interior was performed with the High Resolution Stereo Video System end effector.

Tank WM-188 contains a heel of approximately 11,500 gallons of highly acidic, mixed hazardous waste. A uniform layer of flocculent solids, approximately one-quarter of an inch thick, covers the bottom of the tank. The chemical and radionuclide analyses of the solids and liquid fractions indicate that the heel is heterogeneous. A comparison with previous chemical analyses indicates that chemical stratification did not occur in Tank WM-188. Although very limited pitting was observed, the interior of Tank WM-188 is in excellent condition. Corrosion inside the tank is minimal, and from an integrity standpoint, the tank is completely acceptable for use.

Information from the inspection was incorporated in the Draft High-Level Waste and Facility Disposition Environmental Impact Statement and used to develop closure strategies for the INTEC tank farm. The information was also reported to the State of Idaho to comply with the Third Modification to the Notice of Noncompliance (NON) Consent Order. The sample information is proving invaluable to the development of new treatment flowsheets and waste forms. It is expected that the LDUA will be deployed for tank inspections through the next several years to support other NON Consent Order requirements and several other ongoing initiatives. 


\section{CONTENTS}

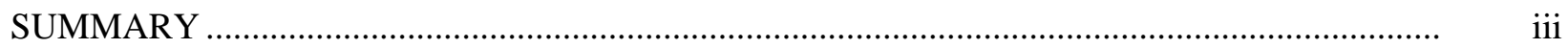

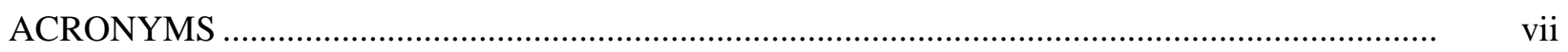

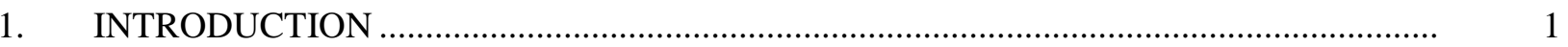

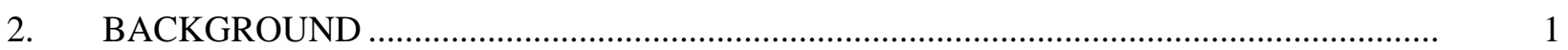

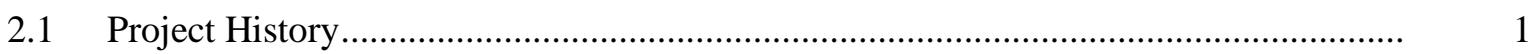

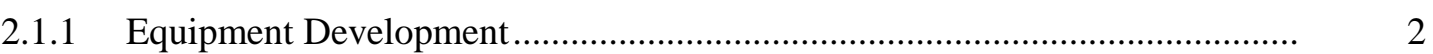

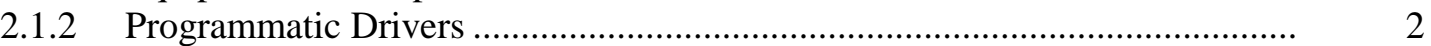

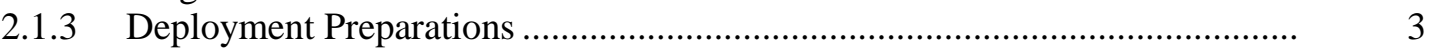

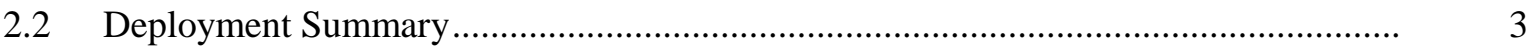

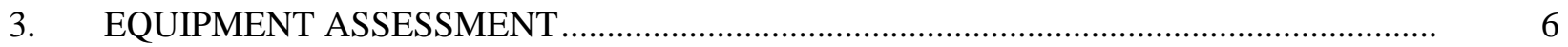

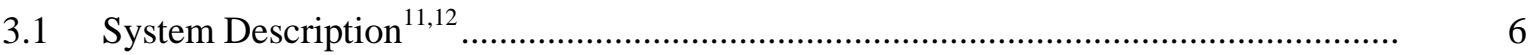

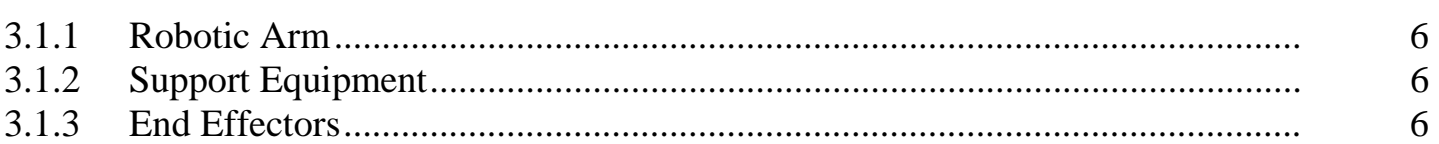

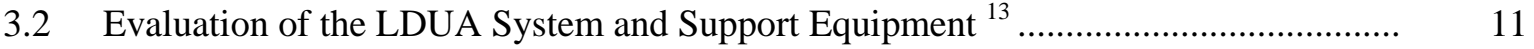

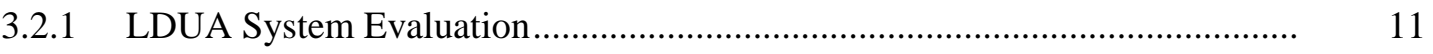

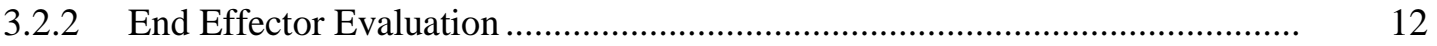

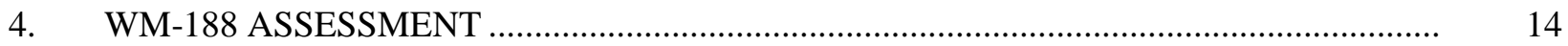

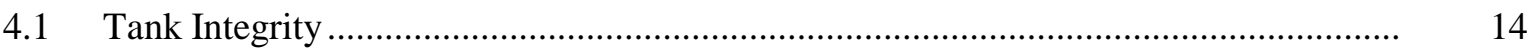

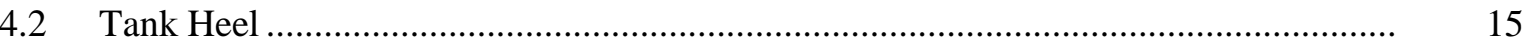

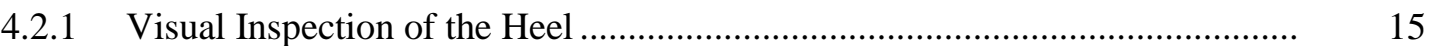

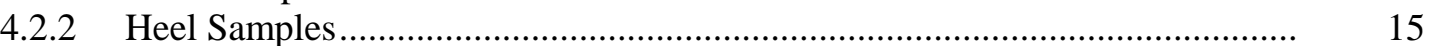

$4.2 .3 \quad$ Additional Heel Evaluations ............................................................. 23

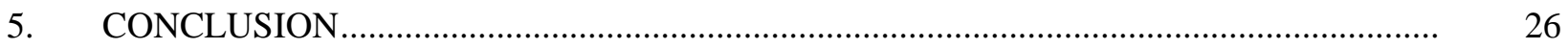

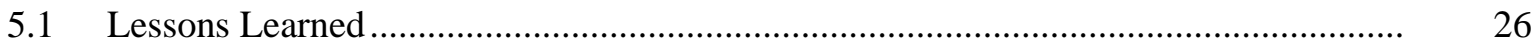

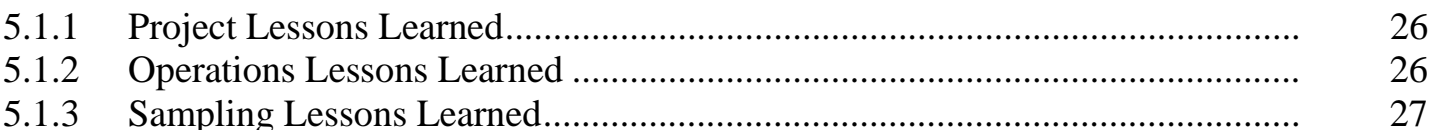




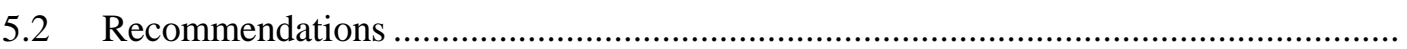

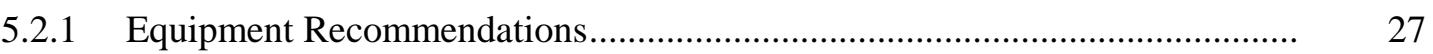

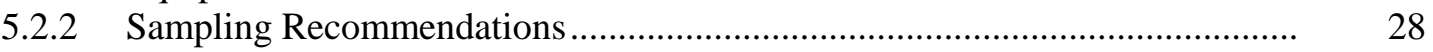

$5.2 .3 \quad$ Programmatic Recommendations............................................................. 28

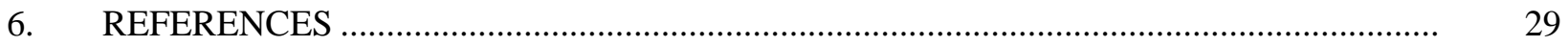

\section{FIGURES}

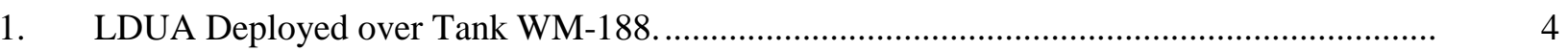

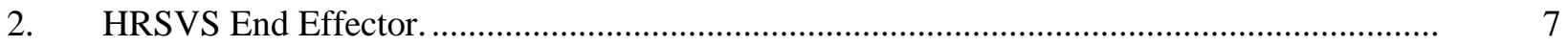

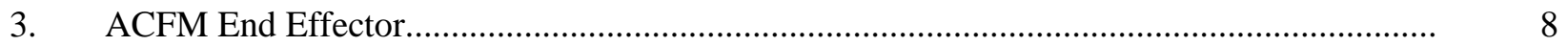

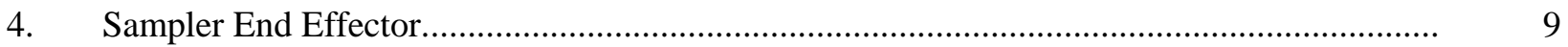

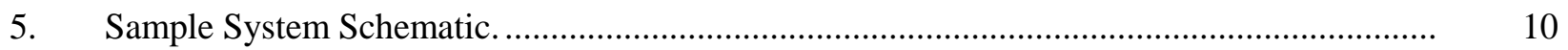

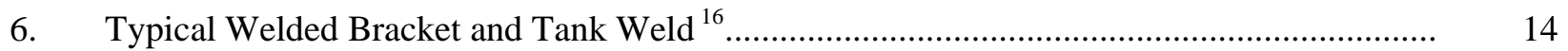

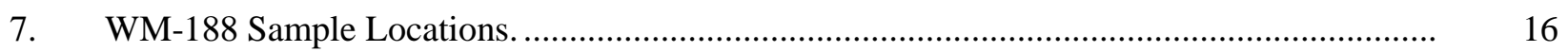

TABLES

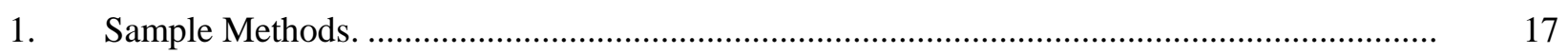

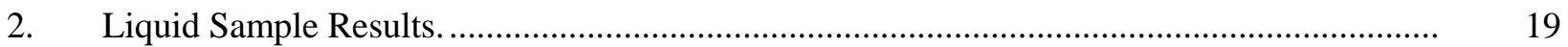

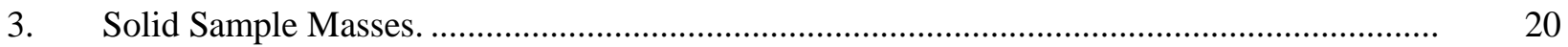

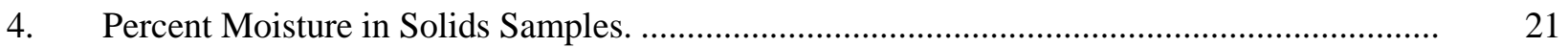

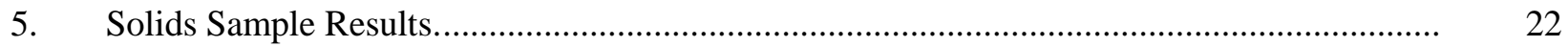

6. $\quad$ Comparison of Liquid Metals Results to Previous Samples............................................ 23

7. $\quad$ Comparison of Solids and Liquids Sample Results........................................................... 24 


\section{ACRONYMS}

$\begin{array}{ll}\text { ACFM } & \text { Alternating Current Field Measurement } \\ \text { DOE } & \text { Department of Energy } \\ \text { EEES } & \text { End Effector Exchange System } \\ \text { FETC } & \text { Federal Energy Technology Center } \\ \text { HLLWE } & \text { High-Level Liquid Waste Evaporator } \\ \text { HLW and FD EIS } & \text { High-Level Waste and Facility Disposition Environmental Impact Statement } \\ \text { HRSVS } & \text { High Resolution Stereo Video System } \\ \text { INEEL } & \text { Idaho National Engineering and Environmental Laboratory } \\ \text { INTEC } & \text { Idaho Nuclear Technology and Engineering Center } \\ \text { LDUA } & \text { Light Duty Utility Arm } \\ \text { NDE } & \text { nondestructive examination } \\ \text { NON/CO } & \text { Notice of Noncompliance Consent Order } \\ \text { OSS } & \text { Oceaneering Space Systems } \\ \text { RAL } & \text { Remote Analytical Laboratory } \\ \text { SSPS } & \text { Still/Stereo Photo System } \\ \text { VPM } & \text { Vertical Positioning Mast }\end{array}$




\section{Light Duty Utility Arm Deployment In Tank WM-188}

\section{INTRODUCTION}

The INEEL Light Duty Utility Arm (LDUA) is one of four computer-controlled, hydraulically operated, telescoping robotic arms designed to inspect and sample large, inaccessible tanks. This report summarizes the development and initial deployment of the INEEL LDUA in Tank WM-188, which contains a residual heel of mixed radioactive waste. The LDUA was moved to the Idaho Nuclear Technology and Engineering Center (INTEC) Tank Farm on February 3, 1999, and deployed in WM-188 on February 11, 1999. The tank inspection continued through March 3, 1999, at which time the LDUA and support equipment were moved off the tank farm and stored. Four heel samples were taken, and a video inspection and a nondestructive examination (NDE) inspection using Alternating Current Field Measurement (ACFM) technology were accomplished. ${ }^{1,2}$

Originally intended as a technology demonstration, the deployment met several other objectives. In addition to the technology demonstration, the sample data obtained were used to refine risk estimates for the High-Level Waste and Facility Disposition Environmental Impact Statement (HLW and FD EIS). It is still being used to formulate tank closure strategies, support an incidental waste determination, and develop process flow sheets for future treatment options of the tank farm waste.

\section{BACKGROUND}

WM-188 is a 300,000-gallon stainless steel tank contained in a square, reinforced concrete vault that meets current seismic requirements. The tank is equipped with cooling coils around the sides and across the floor of the tank. Tank WM-188 was placed in service during June 1963. It was filled five times with highly acidic solutions in the subsequent 25 years - four times with zirconium waste from the separations processes and once with concentrated miscellaneous waste from the High-Level Liquid Waste Evaporator (HLLWE) bottoms. ${ }^{3}$ Tank WM-188 was finally emptied to a heel volume of approximately 11,200 gallons in February 1998. This volume remained constant until the tank inspection with the LDUA in February and March of 1999 and has not changed since. The blended waste remaining in Tank WM-188 is the last of the HLW in the tank farm.

The LDUA technology used in the tank entry resulted from more than a decade of development work at the Idaho National Engineering and Environmental Laboratory (INEEL) in robotic prototypes and end effectors. The trailer-mounted LDUA at the INEEL is the third in a series of four LDUA systems built in Canada by Spar Aerospace Ltd. The LDUA project was administered through the Department of Energy's (DOE's) Tank Focus Area, and funded through DOE's Headquarters Offices of Environmental Management and Science and Technology. INEEL engineers with the Robotics and Remote Systems Program served as the DOE complex technical lead for developing, designing, fabricating, assembling, and testing the robotic arm. The LDUA and its control system were assembled, programmed, and tested last year in the unused Fuel Processing Restoration facility at INTEC and moved to the tank farm in early February 1999.

\subsection{Project History}

The LDUA was purchased by Hanford using INTEC EM-30 funding and delivered to the INEEL late in FY-97. Work started at the beginning of FY-98 and immediately encountered delays and unexpected costs from unanticipated complexity and scope. 


\subsubsection{Equipment Development}

Several key engineers were not immediately available - one engineer left the company, and two others could not be assigned for the first 3 months of the project. A required software upgrade exceeded the cost estimate by $\$ 100 \mathrm{~K}$, and a second software modification was subsequently required. An upgrade to the sample transport system at the analytical laboratory was deferred, requiring a new sample transport system design for the LDUA sample chamber. Equipment testing at INTEC revealed that changing the end effectors in the configuration required for deployment on the tank farm would be extremely difficult, if not impossible. Therefore, an End Effector Exchange System (EEES) was designed and built. ${ }^{4}$

Project work performed in FY-98 included:

1. Equipment checkout and capability testing of the arm

2. Assembling, testing, and interfacing of end effectors

3. Integrating the arm and end effector controls with the operator control consoles

4. Modifying existing support platforms, building new support skids, and trailers

5. Design and fabrication of the EEES

6. Design and fabrication of the sample transport system

7. Training

8. $\quad$ Procedure preparation. ${ }^{4}$

The LDUA deployment was originally scheduled for the summer of 1998 as a technology demonstration. The delays noted were aggravated by two occurrences at the INEEL. First, increased scope and complexity resulted in a stop work order while additional funding was located. The stop work order resulted in lost productivity of approximately 6 weeks. Second, the INEEL experienced a fatality at another facility resulting in a Site-wide stop work order of approximately 1 month. Additional delays due to extra work controls and reviews in response to the fatality can arguably be estimated at 1 to 3 months. The net impact of the delays was to postpone the earliest possible deployment to mid-December of 1998.

The LDUA was not designed to operate in extremely low temperatures, although initial testing of the equipment in Canada was performed in conditions significantly below listed operating temperatures. Testing of the arm at low temperatures in Canada revealed sluggish response due to the increased viscosity of the hydraulic fluid. The support and peripheral equipment developed for the INEEL LDUA were not designed for extremely low temperatures either, because cold-weather use was not anticipated. ${ }^{5}$ Human factors and operational concerns, such as snow loading of the tank farm, make winter deployments on the tank farm problematic. Because of Idaho's severe winter weather, the deployment was originally deferred until late spring or early summer of $1999 .^{6}$

\subsubsection{Programmatic Drivers}

Two factors beyond the control of the project increased the priority of inspecting WM-188 and dictated a deployment before the summer of 1999. First, the HLW \& FD EIS models the risk of tank farm heels and required sample data to support the models. Samples taken in the summer of 1999 could not have been analyzed in time to support the publication schedule for the HLW \& FD EIS. 
Second, the INEEL's Notice of Noncompliance Consent Order (NON/CO) ${ }^{7}$ was modified in August 1998, requiring DOE to submit a closure plan for one of the tank farm tanks by December 31, 2000. The closure plan requires defensible sample data and reliable information about conditions inside the tanks. Since the reviews and approvals for the closure plan are complex, information about the tanks' condition is required early in the plan schedule. The net effect of the NON/CO modification was to elevate the priority of the WM-188 inspection, and allow time for at least one additional deployment of another tank in 1999 to support the submission of a closure plan.

Based on the importance of inspecting and obtaining data, DOE-ID determined that the additional risk involved in a winter deployment was justified and directed that if possible, the LDUA deployment should proceed after instituting additional cold weather controls. ${ }^{8}$

\subsubsection{Deployment Preparations}

During January 1999, LDUA cold weather controls were established, which included insulating and heat tracing susceptible utility lines, covering support trailers with tarps and placing heaters as necessary to minimize the possibility of freezing. The Vertical Positioning Mast (VPM) was modified to supply heated air to the mast. Tank farm load restrictions were met by removing snow from the tank farm with snow blowers. ${ }^{9}$ Extra operational controls and monitoring requirements were proceduralized, and on February 2, 1999, INTEC Operations began moving equipment to the tank farm.

\subsection{Deployment Summary}

From February 2 to February 5, 1999, the major pieces of LDUA equipment were moved to the tank farm. Equipment checkout, functional tests, and operability checks were performed.

Troubleshooting and testing were performed from February 8 to February 10. Equipment setup included all of the cold weather controls, radiological tent construction over the riser, laser alignment of the tank riser, and insertion of an auxiliary camera in adjacent riser TR-27, which is approximately centered in the tank. 


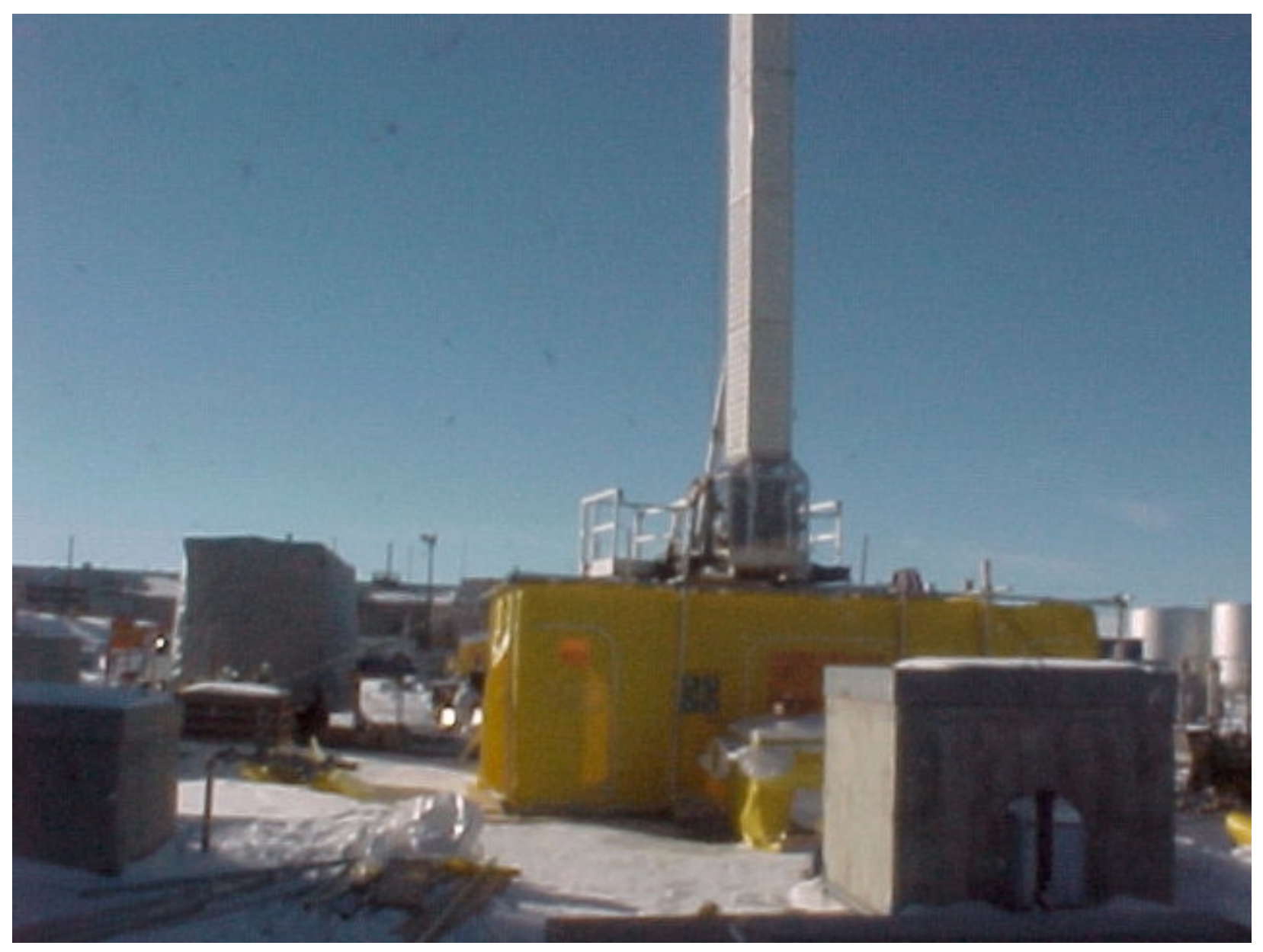

Figure 1. LDUA Deployed over Tank WM-188. 
On February 11, 1999, the LDUA was deployed in Tank WM-188. The High Resolution Stereo Video System (HRSVS) performed an initial video inspection of WM-188 to evaluate sampling locations. The Oceaneering Space Systems (OSS) NDE End Effector, based on ACFM technology, was also deployed to prove functionality for visiting OSS personnel. Both deployments were successful.

The tank heel was first sampled on February 15, 1999, directly below TR-27, the LDUA accessed riser, using Sample Chamber \#3 (analytical log \#990210-4). Approximately 335 milliliters of solution was obtained using the "capture" method (volume is proportional to heel height). Radiation readings on contact with the sample chamber were $400 \mathrm{mRem} / \mathrm{hr} \beta-\gamma$. During retrieval of the sample chamber, a joint boot wedged between the inner and outer masts, which caused the outer mast to rise with the inner mast. A "VPM cable harness too loose" indication was received as the cable unreeved from the drum. The LDUA Project Technical Lead was able to access the VPM, unwedge the boot, and successfully rewind the cable. The first sample was successfully transferred to the Remote Analytical Laboratory (RAL) after recovering from the loose cable condition.

The "volume" method was used with the second and third samples using Sample Chambers \#2 and \#1, respectively. Sample chamber vacuum determines the sample volume in the volume method, and was necessary because the capture method provided inadequate sample volume to perform all required analyses.

Sample \#2 (log \#990210-4) was taken February 16, 1999. The sample chamber was seated, then raised approximately three-eighths of an inch. Based on operator's curves, the sample chamber vacuum was set at 6.5 psi. The sample volume was approximately 686 milliliters, as expected, and on-contact radiation readings were $1,150 \mathrm{mRem} / \mathrm{hr} \beta-\gamma$. The sample was taken approximately 2 feet from the vessel wall.

Sample \#3 (log \#990210-4) was taken February 18, 1999, at full-extension of the arm towards the center of the tank, using the volume method. Sample chamber vacuum and distance from the tank bottom were maintained at the same values as in Sample \#2, and 684 milliliters were collected. On-contact radiation readings were $1,200 \mathrm{mRem} / \mathrm{hr} \beta-\gamma$, which is very consistent with Samples \#1 and \#2. Some contamination, attributed to dripping from the exterior of the sample chamber or contamination spread from the sample transfer container, was noted in the tent when this sample was placed in the transfer cart. Decontamination of the tent was necessary before the deployment of the next end effector, and the transfer cart and sampler chambers were sent to the Decontamination Facility after the third sample.

On February 23, 1999, a general inspection of the heel and physical conditions inside WM-188 was conducted with the HRSVS. The suction jet area was evaluated as a fourth sample location. The inspection included examination of approximately $25 \%$ of the accessible welds, examination of two 3-foot square sections - 18 inches and 72 inches above the tank bottom, respectively - and examination of several cooling coil supports. No appreciable defects or corrosion was noted, although a few areas of small pitting were observed. The pitting areas were scanned on February 24, 1999, with the ACFM End Effector, but no measurable flaws were detected.

The last end effector deployment was on March 2, 1999, to sample the tank heel for a fourth time. An additional sample was taken in the hope that enough solids mass to perform all of the analyses in the sample plan would be obtained. The fourth sample (log \#990301-6) was taken approximately 18 inches from the jet suction using the same volume method used in Samples \#2 and \#3. Approximately 591 milliliters of noticeably darker (coffee colored) solution was obtaining, reading 3,000 mRem/hr $\beta-\gamma$ oncontact. $^{1,2,10}$

Following the fourth sample, the LDUA and associated support equipment were removed from the tank farm over a period of several weeks. 


\section{EQUIPMENT ASSESSMENT}

In general, the LDUA and associated support equipment worked extremely well. All of the deployment objectives were met despite deploying in extreme winter conditions. Operations continued through daytime temperatures as low as 6EF and sustained winds of 23 to 25 miles per hour, with gusts up to 30 miles per hour. The majority of the problems experienced were relatively minor and many were associated with the cold weather modifications.

\subsection{System Description ${ }^{11,12}$}

The LDUA system is comprised of three subsystems: (1) robotic arm and deployment platform; (2) support equipment; and (3) end effectors, which attach to the tool interface plate on the end of the arm and perform different functions in the tank.

\subsubsection{Robotic Arm}

The LDUA robotic arm is a seven-jointed manipulator with a horizontal reach of 13.5 feet and a payload capacity of 75 pounds. The manipulator is deployed from a telescoping, Vertical Positioning Mast (VPM) consisting of two concentric cylinders housed in an environmentally tight housing. The VPM is mounted on a trailer, lying horizontally when transported, but raised to a vertical position by a hydraulic ram for deployment. Fully deployed, the arm extends 482 feet below the VPM housing.

\subsubsection{Support Equipment}

The LDUA is operated remotely from a control trailer, which houses the computer controls, graphic interfaces, and joystick necessary to deploy the arm. The arm can also be operated locally from a control pendent. In addition to the Control Trailer, instrument integration, electrical, hydraulic and pneumatic support systems are mounted on skids, which in turn sit on trailers for transport. Including the LDUA Trailer and Control Trailer, there are a total of four trailers.

Remote exchange of the end effectors between the TIP and a rack inside the containment tent is accomplished by the End Effector Exchange System (EEES). It also provides a means of detaching a sample chamber and placing it inside a transport container for transfer to the analytical laboratory. A spray ring for gross decontamination of the arm and an independent camera system inserted in a separate riser were also used in the WM-188 deployment.

\subsubsection{End Effectors}

Idaho currently has six end effectors for the LDUA. Two - an NDE end effector based on eddy current technology developed by ZETEC, Inc., and a Still/Stereo Photo System (SSPS) end effectorwere not sufficiently developed or tested for deployment in WM-188. The remaining three-HRSVS, ACFM, and Sampler-were successfully deployed. Development of the sixth end effector-a gripper was initiated after the WM-188 deployment.

3.1.3.1 High Resolution Stereo Video System End Effector. The High Resolution Stereo Video System (HRSVS) end effector provides a three-dimensional image for inspecting tank interiors and waste. A special lens system provides zoom capabilities. At any standoff distance, the size of the viewing area is known, which allows accurate sizing of the subject. 


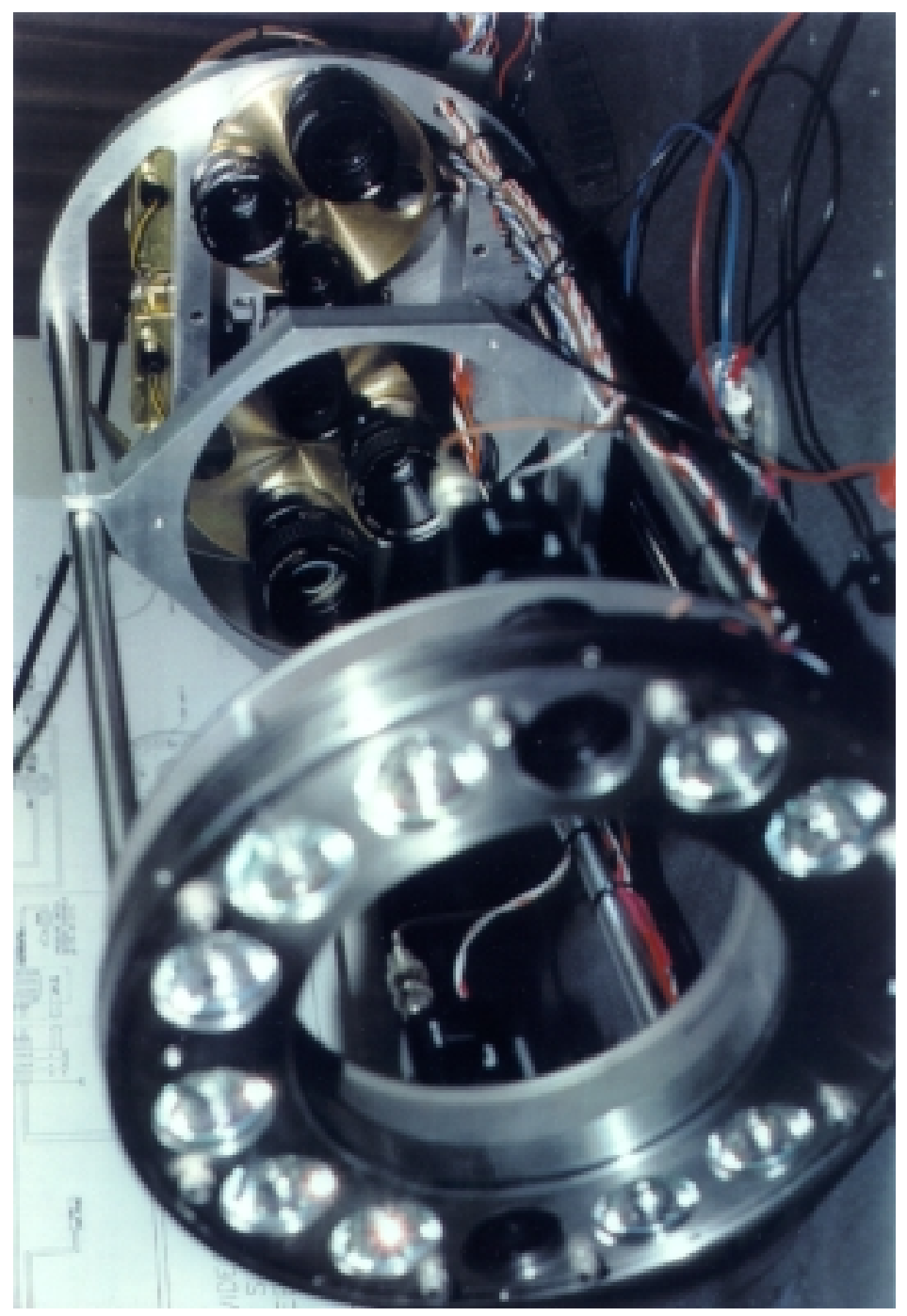

Figure 2. HRSVS End Effector.

The lens system uses a pair of color video cameras that provide a stereoscopic image to aid in the differentiation between pits and bumps. Fixed intensity lights in the lighting system can be turned on and off in pairs to shadow the viewing area, further improving the operator's perception. Two additional cameras with separate fixed focus lenses provide an overview and are used to guide the arm to an area for closer inspection.

NOTE: The HRSVS was modified because the cameras and lenses could not be kept in focus and alignment - the cameras were hard mounted inside the end effector housing, eliminating focus and zoom capabilities. The components are fixed, so focusing is achieved by moving the arm.

3.1.3.2 Alternating Current Field Measurement End Effector. The Alternating Current Field Measurement (ACFM) end effector was developed by Oceaneering Space Systems, Inc., of Houston, Texas, in cooperation with the Federal Energy Technology Center (FETC), and is used to support evaluations of the structural and containment integrity of the tank. It was designed to perform a "flyby" scan of the tank surfaces and identify suspect areas for more detailed examinations. Additionally, the end effector was modified for submersion in liquids (this feature was tested before deployment but was not performed in Tank WM-188). 


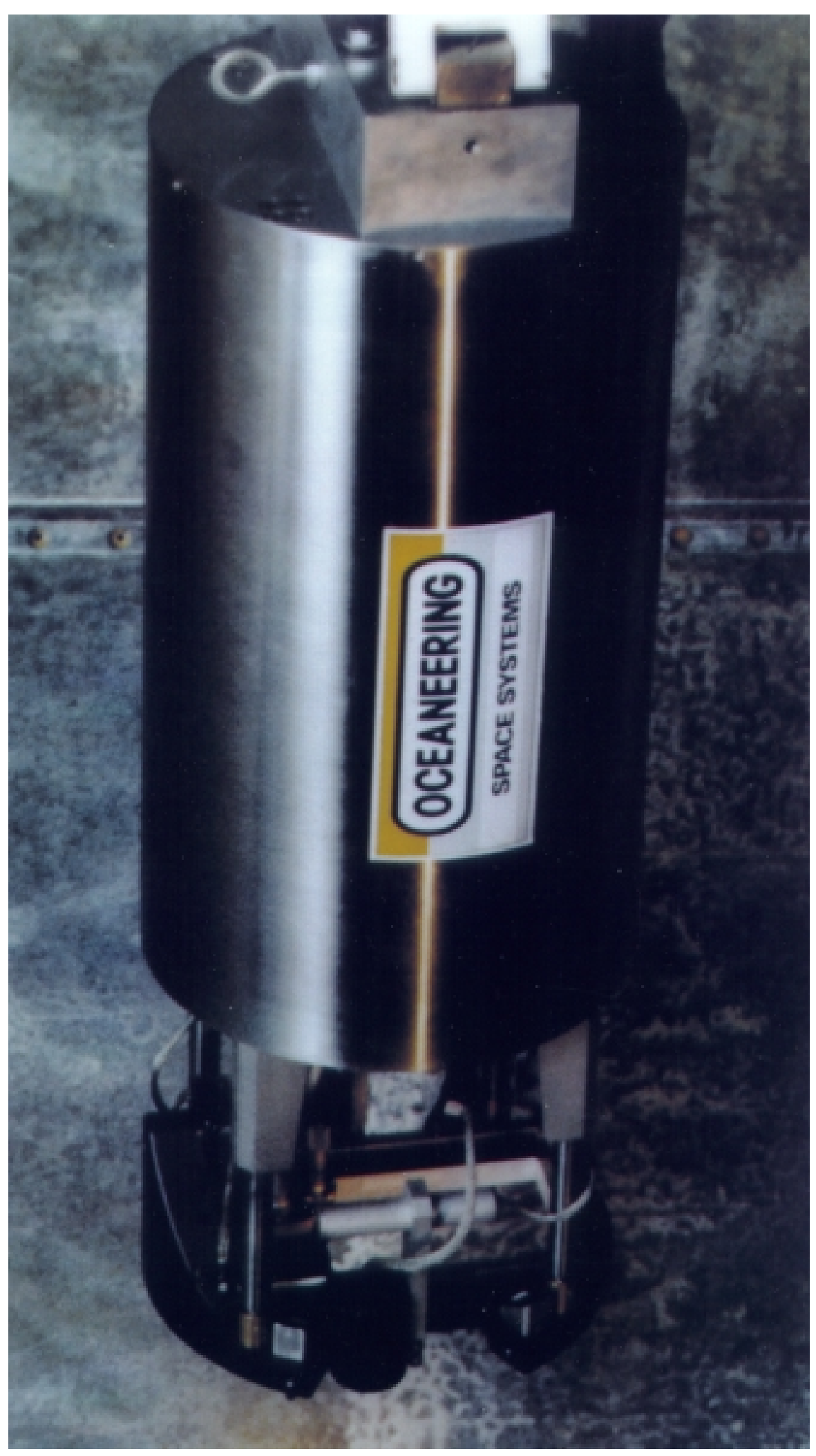

Figure 3. ACFM End Effector. 
The ACFM End Effector detects and measures cracks, wall thickness, and pits in stainless steel walls and tank wells. The flyby resolution of the end effector for cracks is 0.5 inches long and 0.25 inches deep. For pits, the resolution is 0.25 inches in diameter and 0.25 inches deep. Measurements are made based on changes, induced by defects in the measured surface, in an electromagnetic field. The field is created by the alternating current in the scanning head. (Conventional NDE methods in the United States are based on eddy current technology, although alternating current is used widely in Europe. Part of OSS's purpose in developing the end effector was to demonstrate the technology in the United States.)

During deployment, the end effector is activated once the scanner is activated and the data are transmitted to the Control Trailer for "real-time" analysis or electronic storage for analysis at a later date. Trained OSS personnel analyze the data retrieved from the scanned head.

NOTE: The flyby capabilities of the ACFM End Effector were not used or tested because the INEEL NDE End Effector was not available for confirmation and comparison of data.

3.1.3.3 Sampler End Effector. The Sampler End Effector was designed and fabricated at the INEEL, and includes a camera, variable intensity lights, a radiation detector, and the sampling system. The sample system establishes a vacuum in the sample chamber, then pulls waste into the chamber when the valve between the chamber and tank heel is opened. Solution is drawn to the sample chamber through a capture tube that is inserted in the waste, while the sample chamber remains suspended above the liquid heel. A picture of the Sampler End Effector is shown below.

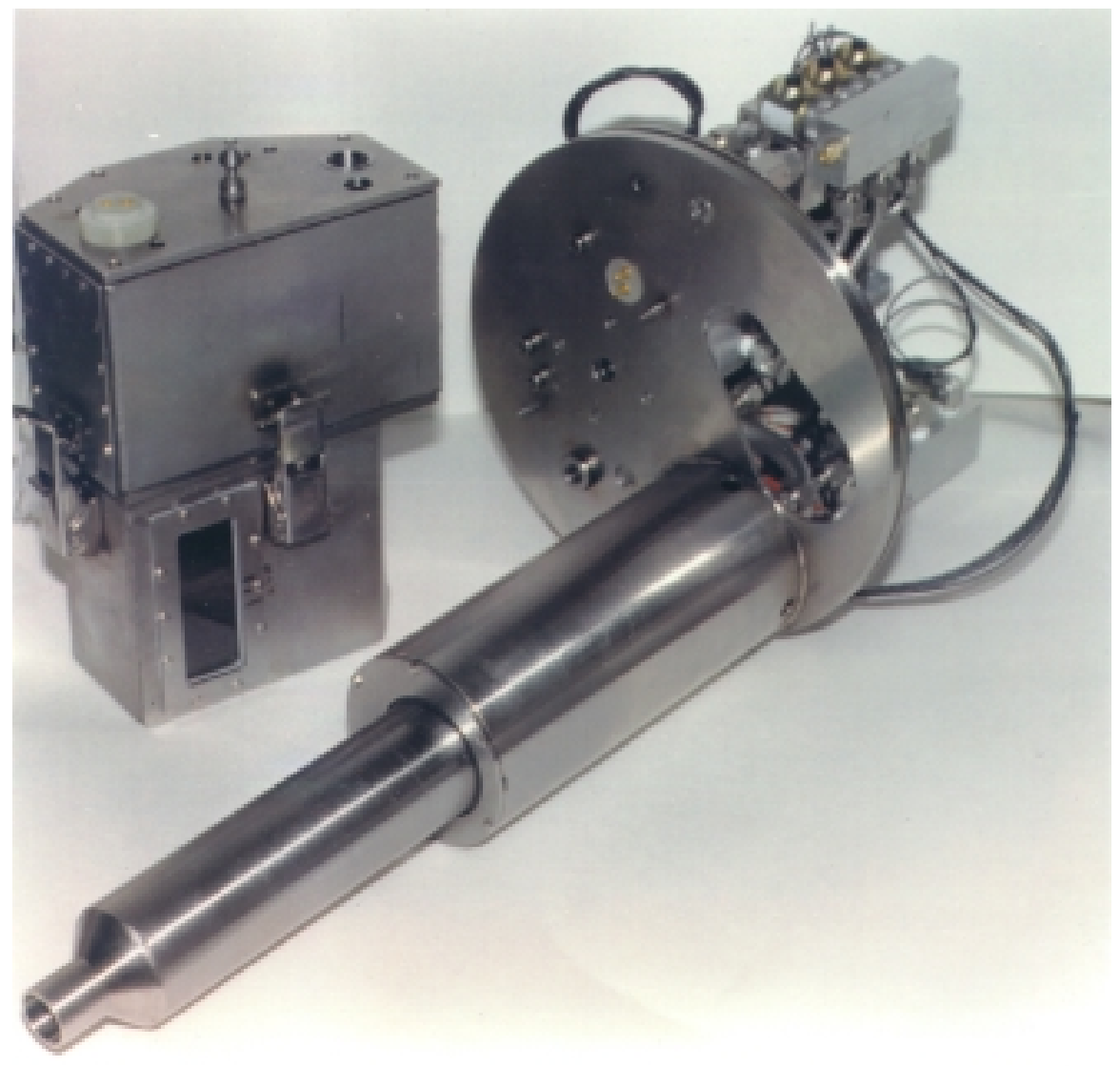

Figure 4. Sampler End Effector. 


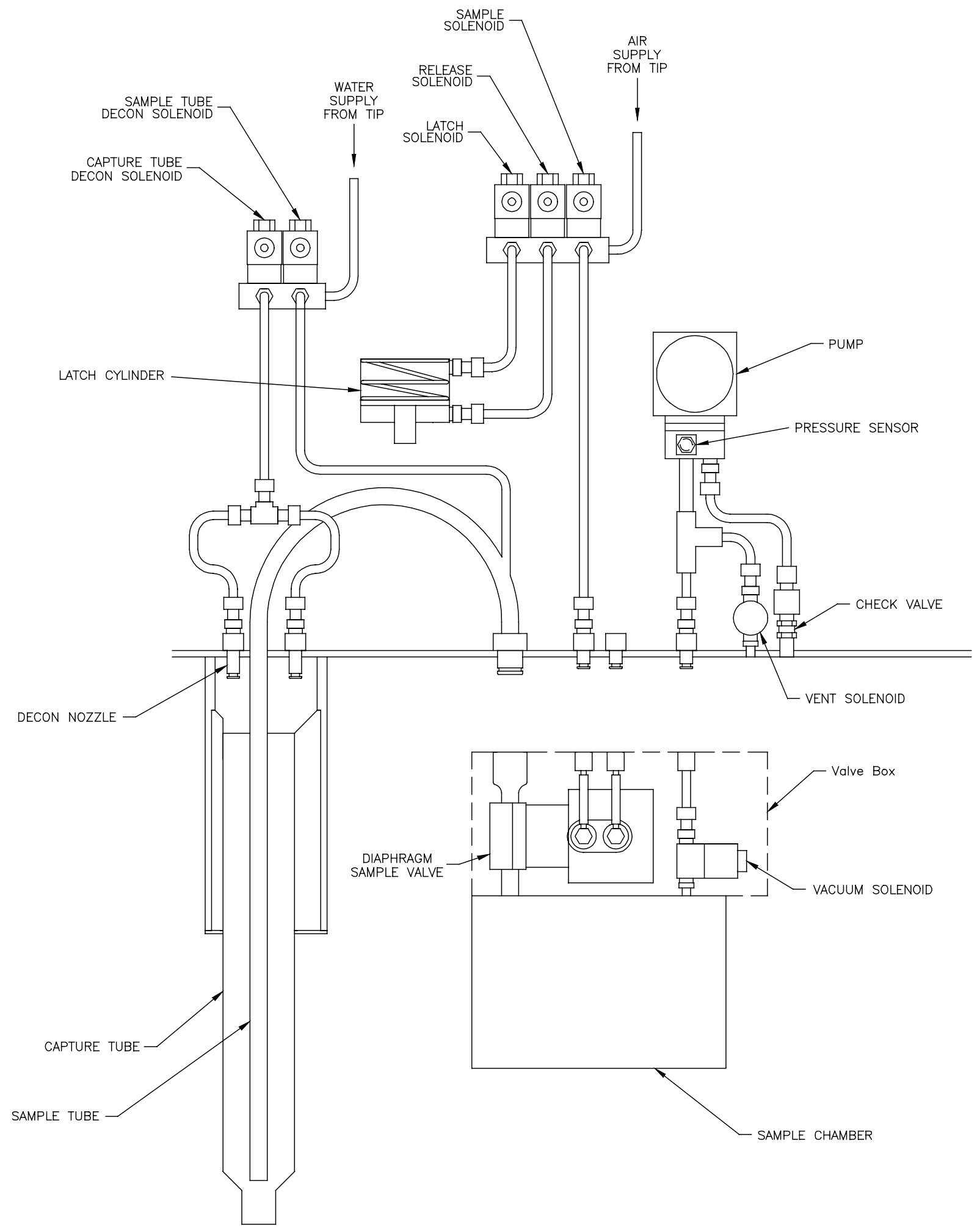

Figure 5. Sample System Schematic. 
Two methods are used to control the sample volume. In the capture method, the capture tube is seated on the bottom of the tank. The sample volume is essentially the solution inside the capture tube, and the volume sampled is proportional to depth of the heel. In the volume method, the capture tube is lifted off the bottom of the tank and the sample chamber vacuum determines the sample volume. When the isolation valve is opened, solution is drawn into the sample chamber until the pressure in the chamber equalizes with the tank pressure. The relationship between vacuum and volume is known and controlled by the operator in the control trailer. A schematic of the sample system is shown below.

The sample method is chosen by considering the tradeoff between required volume and accurate representation of the solids mass on the bottom of the tank. In either method, when the sample is drawn, the isolation valve is closed and the sampler is withdrawn from the heel. Verification of a successful sample is possible with a sight glass and observation of sample chamber pressure changes in the control trailer. Sampling of the headspace above the sample solution is possible in the laboratory through two septa ports in the upper part of the sample chamber.

\subsection{Evaluation of the LDUA System and Support Equipment ${ }^{13}$}

\subsubsection{LDUA System Evaluation}

The arm and support equipment functioned very well during the deployment. Sluggish performance was expected from the cold and subsequent increase in the mineral oil's viscosity. This was not observed and the arm proved very responsive. Although listed here as equipment problems, many of the problems relate as much to the weather or inexperience as they do to equipment deficiencies. Most issues, such as increasing the speed of the EEES, are easily addressed and will be adjusted before the next deployment. The four notable problems related to the cold weather are:

A 3-foot section of the washdown line was not heat traced and froze during operations.

The gate valve froze in place during the later parts of the deployment. This resulted from leaving the valve open to take advantage of the heated air inside the tent. Consequently, moisture collected in the lower section of the arm, which froze when the gate valve was subsequently commanded to close.

The Control Trailer was very cold and requires a substantially larger heat source for winter deployments.

The washdown system filled the tent with mist when it was blown down at full pressure from the air compressor. Following the next washdown, the line was not blown and it froze. Subsequent blowdowns were performed successfully by altering the sequence and lineup of the system.

Another more serious problem was unrelated to the cold weather. The pendant continually lost communications with the arm and required a "VME Reset" to recover. The reset was effective in recovering communications, but was required so often that the mast was raised and lowered from the Control Trailer. Although the communications problem was experienced during System Operability (SO) testing, the frequency increased dramatically following the SPAR modifications in August 1998.

The problems related to cold weather are not expected to reoccur in subsequent warm-weather deployments, and if an unanticipated winter deployment becomes necessary again, additional mitigating actions will not be extensive. In general, the arm and support equipment performed very well and only the pendant communications problem is considered significant. 


\subsubsection{End Effector Evaluation}

Only the three deployed end effectors - HRSVS, ACFM, and Sampler - were evaluated. Development of the ZETEC NDE and SSPS End Effectors was not sufficiently advanced to deploy them in WM-188. Design of a sixth end effector - a gripper — was initiated after the deployment. Their performance will be evaluated in the future after they are actually deployed in a tank.

3.2.2.1 HRSVS End Effector. Inside the tank, this end effector functioned very well. However, many of its capabilities were removed before deployment due to problems with the lenses during testing. The lens carousel did not function reliably; hence, three of the lenses were removed before deployment, which prevented viewing all areas of the vessel. The only lens used during the deployment had a fixed 36-inch focal length. The quality of video was excellent, but all of the end effector's capabilities could not be exploited. $1,10,13$

3.2.2.2 ACFM End Effector. The ACFM was the first end effector deployed. It was landed and performed numerous scans with minimal trouble. Because the INEEL NDE end effector was not deployed to allow data comparison and the OSS engineers were only available to support operations for a short time, the flyby feature was not tested. The end effector was redeployed without OSS support on February 24, 1999, and scanned some visible construction defects on the side of the tank. The end effector did not detect the defects, but the operators saved three scans in an electronic file for later analysis by OSS engineers. After analysis, the OSS engineers suggested that the end effector worked correctly, but the defects were too small to be detected. Hence, further development may be necessary to improve the precision of the ACFM End Effector for useful application in the INEEL Tank Farm.

When the ACFM End Effector was positioned with the arm fully extended, it was difficult to obtain landing indication on all three landing lights due to the rotate function tripping on high torque. During SO testing, the shoulder was the most sensitive joint, which may result from an overly conservative trip setting. It is also possible that the tolerances on the struts and/or landing lights may be too tight. Either cause may effectively limit the useful reach of the arm during deployment of this end effector. ${ }^{10}$

One other observation of the ACFM End Effector is notable. Sustained winds during the second ACFM deployment were approximately 17 miles per hour. The arm was observed jumping and correcting as the end effector landed on the wall. This probably did not affect the data, but indicates that the wind is more limiting for NDE operations than for operations with the other end effectors, and may also limit the useful reach of the arm in moderate-to-high winds. ${ }^{1,13}$

3.2.2.3 Sampler End Effector. In general, the sampler worked very well. Both methods of sampling - capture and volume - were successfully demonstrated. The sight glass proved a valuable tool in verifying solution had entered the sample chamber, and the solids on the bottom were successfully sampled. Gas sampling in the laboratory confirmed that the septa ports could be used to sample the headspace, although sample results from the headspace were too ambiguous to quantify the effects of headspace vacuum on organics in the sample. However, laboratory tests ${ }^{14,15}$ on surrogate heel solutions spiked with volatile and semivolatile organics indicate the effects of vacuum are small and can be quantified. Sample results will be discussed in more detail later in the report.

Sample \#1 was a capture sample and the solids collected are representative of the actual quantity of solids in the heel. Estimates of the solids depth in WM-188 are approximately $1 / 4$ inch, based on observations in the visual inspection. Based on bulk density and the area covered by the capture tube, the calculated depth of heel is about 0.16 inches. This calculation does not account for partial suspension of the lighter solids increasing the solids depth. Given the qualitative nature of the visual inspection, the 
extensive remote handling of the solids, and the solids' flocculence, closer agreement cannot be reasonably expected.

Samples \#2 and \#3 were volume samples for which the vacuum was set to draw 700 milliliters. Both sample volumes were approximately $98 \%$ of the expected volume. Sample \#4 was drawn at a lower vacuum and the volume was correspondingly lower.

Three items of interest were noted. First, Sample \#1 did not draw as much volume as expected. The sample volume was 25 to $30 \%$ lower than expected for the reported heel depth in WM-188. Although this did not affect the quality of the samples, it should be considered in the future when determining the type of sample to be drawn. Second, the original design requirements of the capture tube minimized the solids in the sample for ALARA concerns. Hence, the tube diameter necks down to approximately 1 inch. In the time period since the sampler was designed, the need for solids analyses has grown. As evidenced in this sampling effort, inadequate solids mass is problematic and modification of the sampler or modification of sample methods may be necessary to sample solids to meet all future needs. 


\section{WM-188 ASSESSMENT}

The conditions in Tank WM-188 were evaluated based on the LDUA inspection. The tank integrity section is generally qualitative - it is based on the visual inspection and the limited data from the ACFM inspection. The tank heel section is qualitative and quantitative - it is based on the visual inspection and the sample analysis from four heel samples.

\subsection{Tank Integrity}

Generally, the condition of the tank was very good and the physical condition WM-188 is completely acceptable for use. The visual inspection showed only minor corrosion attack. The ACFM End Effector did not detect any defects, although these results are inconclusive because the end effector did not detect known physical damage. Corrosion coupons suspended through a tank riser in 1988 have been hung up in the riser since their installation. Since they were only exposed to the vapor phase, no useful information was obtained from the coupons.

Two suspect areas, selected earlier for their pits and indentations, were inspected with the ACFM End Effector. Based on shadow conditions, the depth of the pits was estimated at 2 to 3 mils deep. The pits were apparently produced during fabrication of the vessel and do not show any discernible growth or propagation. Scans of areas did not detect the pits and indentations due to the minimum detection limits of the end effector. ${ }^{16}$

The tank wall, cooling coils, internal piping, supports, and welds were visually inspected. Approximately $25 \%$ of welds were evaluated. A typical welded bracket for cooling coil support and typical tank weld are shown below.

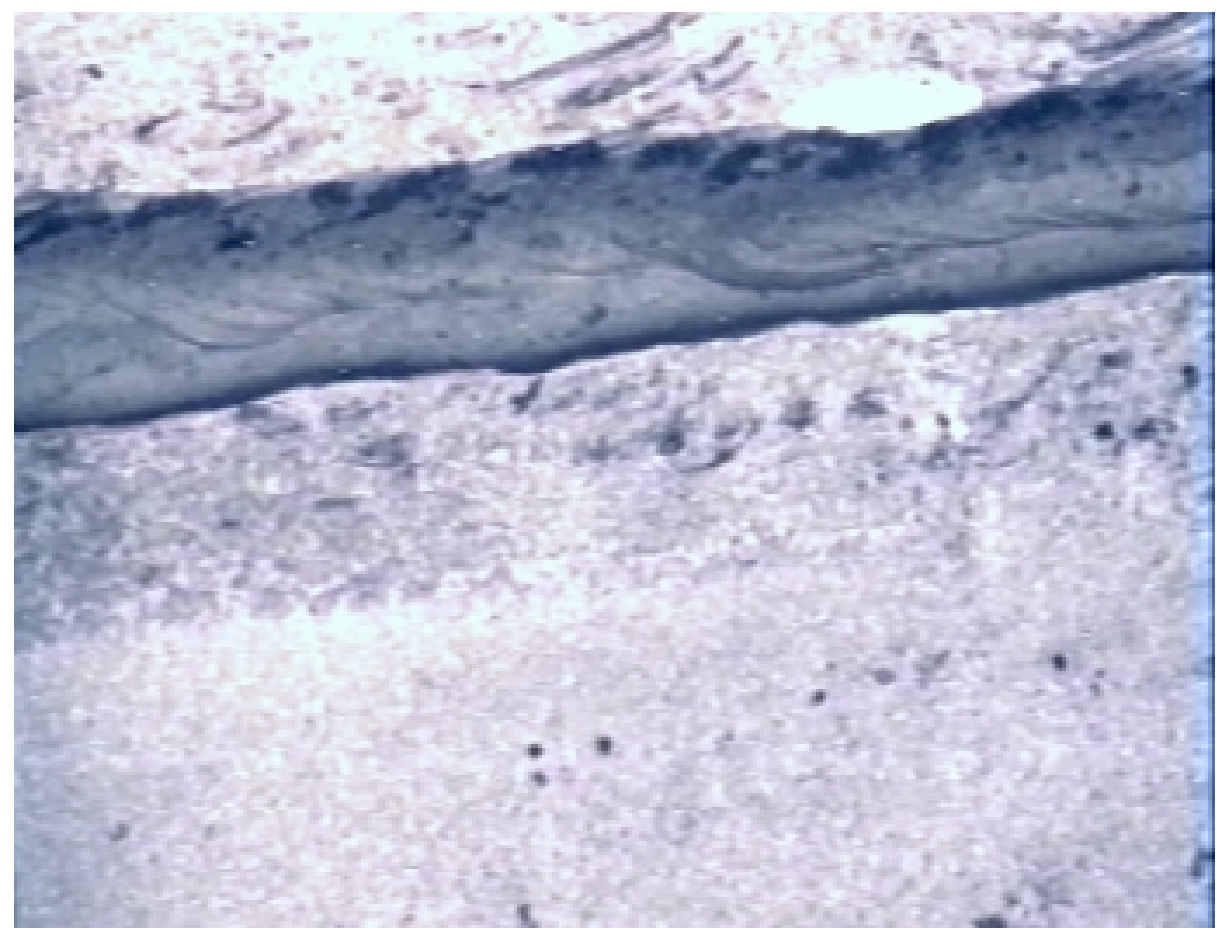

Figure 6. Typical Welded Bracket and Tank Weld ${ }^{16}$ 
All of the equipment inspected showed little or no indication of corrosion. Small, localized pitting was observed as noted above, which was attributed to fabrication. Grinding patterns and other marks from fabrication are still readily apparent on the tank wall. They show no sign of deterioration or propagation. None of the observations indicate that the tank's integrity is suspect.

Crystalline deposits were observed on top of the cooling coils and supports in the lower regions of the tank. There appeared to be no localized corrosion corresponding to the deposits. Black "bathtub ring" marks on the tank wall correspond to the various liquid levels in the tank over the past 35 years. The bathtub ring marks rise from the heel to a height that roughly corresponds to a 285,000-gallon level in the tank. Black, scumlike material also adheres to the piping and supports in the tank. Based on video from previous inspections, this material is expected to come off the walls with reasonable effort. In the previous inspection, a garden hose was sprayed on the wall in a different tank, and similar material on the wall washed off readily. ${ }^{17}$

Although capable of submersion, the ACFM End Effector was not inserted below the heel during this deployment. A good visual examination of the bottom and knuckle region could not be conducted due to the reflections from suspended solids in the heel. ${ }^{16}$

\subsection{Tank Heel}

Investigation of the tank heel was made to support four efforts: source term definition for the HLW \& FD EIS, definition of a chemical baseline for RCRA closure of the tank farm, WIR determination for the tank heels, and development of process flowsheets. General observations of the heel condition from a visual inspection and chemical analyses from sampling were performed. In support of all three efforts, the capabilities of the laboratory were tested to determine if additional method development is necessary to support full characterization of heels sampled in the future.

\subsubsection{Visual Inspection of the Heel}

The measured depth of the heel was between 9 and $91 / 2$ inches, ${ }^{10}$ corresponding to a volume between 11,000 and 11,600 gallons. The measurement was inferred from the travel of the arm as recorded on the control computer. There is no organic layer floating on the heel, but a discontinuous, scumlike material is randomly distributed across the entire surface.

There is no visual indication of solids buildup in the heel, including the area around the jet suction. During the video inspection, the top of a bracket, welded to the bottom of the tank, was observed. The bracket holds a cooling coil support and is $3 / 8$ inch tall. Since the top of the bracket was visible, it can be deduced that the tank solids are less than $3 / 8$ inch thick. Comparing this observation with the solids sample data, the thickness is actually estimated at approximately 1.4 inch. Consistent color, reflection, and penetration of light indicate that the heel is of a homogeneous nature.

\subsubsection{Heel Samples}

The original sample strategy for WM-188 was to take three samples in a line from the exterior wall towards the center of the tank, as far as the arm would reach. Where possible, RCRA protocol was applied to the samples to allow an "apples-to-apples" comparison to other samples and to identify shortfalls in sample and analysis capabilities. This strategy identifies trends across the tank and initiates method development and improvements for future LDUA sampling activities.

Three capture samples were originally planned for WM-188, but the first sample did not yield enough volume to perform all of the required analyses. Approximately 300 milliliters is required for 
semivolatile analysis, and this analysis was omitted from the first sample. Samples 2 and 3 were taken using the volume method, with a target of 700 milliliters per sample. A fourth sample, using the volume method, was added to supply a third semivolatile analysis and to obtain more solids (It was apparent after the first sample that more solids were needed.). ${ }^{18}$

4.2.2.1 Sample Locations. Tank WM-188 was sampled approximately 18 months after it was emptied, during which time the tank was isolated. The first three samples were taken in a straight-line pattern from the exterior wall towards the tank center, as close to center as the arm would reach. This sample pattern was chosen to allow a comparison of the sample results across the radius of the tank and to facilitate the evaluation of the heel's homogeneity. The fourth sample was taken approximately 18 inches from the jet suction from which the tank contents are emptied. This location was selected after visual inspection for the following reasons:

The local effect of the jet's vortex on the heel solids is unknown. Sampling at the jet suction could reasonably be expected to demonstrate localized deviations in solids loading.

The jet suction was at the arm's maximum reach in a direction away from the first three samples, allowing better evaluation of homogeneity across the tank bottom in a nonradial direction.

Although only a qualitative measure, the static on the video from the heel's radioactive field appeared to increase as the arm approached the jet. Since the solids are more radioactive than the liquid, it was assumed that this indicated a higher solids concentration at the jet suction.

The diagram below shows the location of all four samples in Tank WM-188. The distances shown are approximate.

\section{WM-188 Sample Locations}

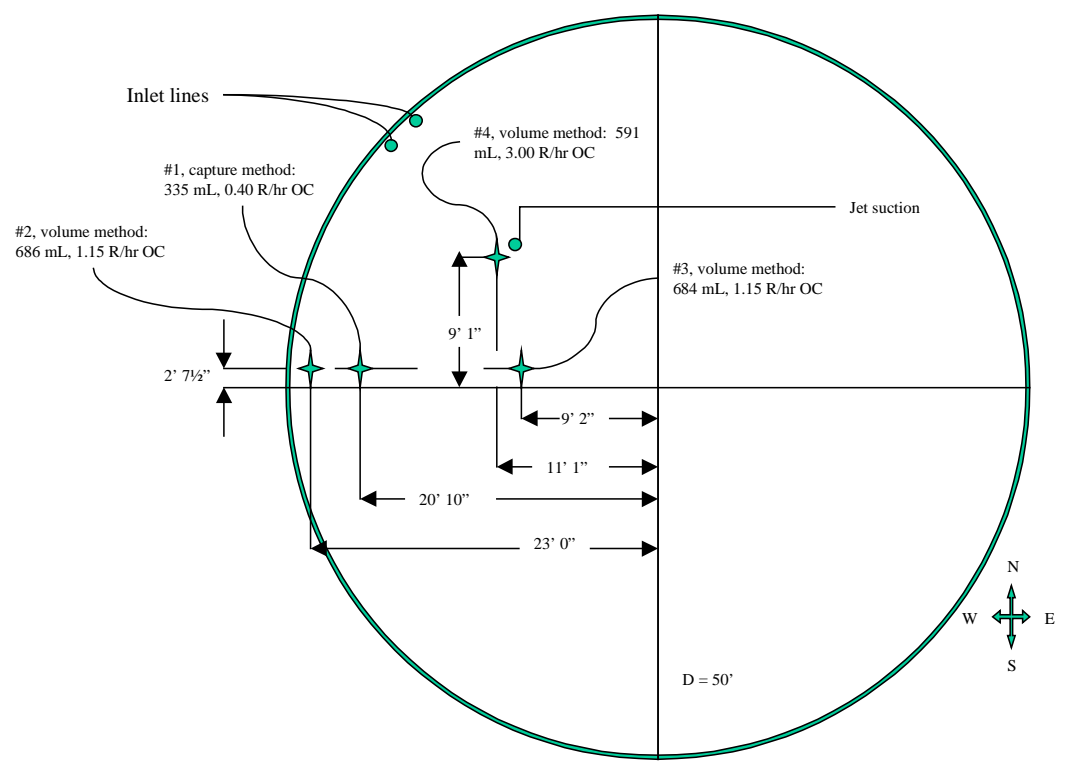

Figure 7. WM-188 Sample Locations. 
4.2.2.2 Sample Methods. All sample analysis activities were initiated in the Remote Analytical Laboratory (RAL) facility, which has the capability to analyze highly radioactive process materials by using the most modern laboratory apparatus. Waste analysis performed by the RAL using the Analytical Chemistry Methods Manual (ACMM) was performed in accordance with EPA-SW-846 Methods whenever possible. ${ }^{8,9}$ These methods correspond to the methods used in the Sampling and Analysis Plan for Implementation During NWCF Campaign $\mathrm{H}-4$, to improve the comparability of heel samples and samples taken earlier when the tank volume was higher. The table below identifies the methods used for most waste characterization analyses of WM-188.

Table 1. Sample Methods.

\begin{tabular}{|c|c|c|c|c|c|c|}
\hline \multirow[t]{3}{*}{ PARAMETER } & \multicolumn{4}{|c|}{ SAMPLE PREPARATION } & \multicolumn{2}{|c|}{ TEST METHOD } \\
\hline & \multicolumn{2}{|c|}{ ACMM METHOD } & \multicolumn{2}{|c|}{ SW-846 METHOD } & \multirow[t]{2}{*}{$\begin{array}{c}\text { ACMM } \\
\text { METHOD }\end{array}$} & \multirow{2}{*}{$\begin{array}{c}\text { SW-846 } \\
\text { METHOD }\end{array}$} \\
\hline & LIQUID & SOLID & LIQUID & SOLID & & \\
\hline Total Metals: & $7900 / 2900$ & $7900 / 2900$ & NA (1) & NA (1) & $7900 / 2900$ & 6010 \\
\hline Total Metals: $\mathrm{Hg}$ & $2800 / 7802$ & $2800 / 7802$ & 7470 & 7471 & 2800 & $7470 / 7471$ \\
\hline $\begin{array}{l}\text { Volatile Organic } \\
\text { Compounds }\end{array}$ & 9354 & $8998 / 9354$ & 5030 & $\begin{array}{l}1311 / 503 \\
0\end{array}$ & 8260 & 8260 \\
\hline $\begin{array}{l}\text { Semivolatile } \\
\text { Organic } \\
\text { Compounds }\end{array}$ & 9500 & $8998 / 9500$ & 3510 & $\begin{array}{l}1311 / 355 \\
0\end{array}$ & 9270 & 8270 \\
\hline \multirow{3}{*}{$\begin{array}{l}\text { Beta - Alpha } \\
\text { 1) Actinides } \\
\text { 2) Plutonium }\end{array}$} & 3000 & 3000 & NA & NA & & \\
\hline & & & & & 3200 & NA \\
\hline & & & & & 3998 & NA \\
\hline Strontium & & & & & $3381 / 3384$ & NA \\
\hline Gamma & NA & NA & NA & NA & 3993 & NA \\
\hline
\end{tabular}

a. The liquid samples are strong acid solutions and the $\mathrm{HCl}$ digestion is not performed on hot cell samples.

Other constituents, for example PCBs (ACMM method 9080), were analyzed without RCRA protocol to provide information for other initiatives. The special requirements for handling samples with high radiation levels require that the samples be received and analyzed (or sample preparations completed) in a remote analytical cell. This is true of the WM-188 samples and all other samples above radiation trigger levels.

The remote sample handling requirements and specific process requirements caused deviations in some required analyses systems. For example, volatile organic samples were not transported at 4EC, which is a required preservation technique. However, once the VOC samples were received at the hot cell, the samples were transferred to VOA vials with intact septums to create VOC samples with no headspace. The samples were chilled with ice in coolers to prevent volatilization of the organics, which is the intent of the requirement. Addition of acid to reduce $\mathrm{pH}$ to less than 2 is a required preservation technique for liquid metal samples. Since the $\mathrm{pH}$ of WM-188 liquid is much lower than 2 , and the 
radiological nature of the waste prevents biological degradation, this preservation technique was not employed. Again, the intent of the requirement was met. Additional minor differences exist between ACMM and SW-846 methods. The differences are documented in the analytical report narratives and had little or no impact on the data quality.

Compounds found in the volatile organics or semivolatile organics analyses that were not identified on the analyte list were subjected to a spectral library search. Spectral library searches were performed on ions not in the analyte list, with relative intensities greater than $10 \%$ of the most abundant ion. Spectral library searches were limited to $10 \mathrm{VOC}$ and 20 SVOC nonsurrogate compounds of greatest concentration.

4.2.2.3 Sample Handling and Preparation Procedures. Handling and preparation of the samples was a complicated and labor intensive effort. A detailed description of the process required in excess of 50 notebook pages. This section is a summary of the detailed procedure for all of the samples.

Each time the Sampler End Effector was removed from Tank WM-188, the sample chamber was detached from the LDUA and placed in the transfer container. The sample chamber was transferred to the RAL, placed on the RAL transfer cart, and moved inside the hot cell. Inside the hot cell, the sample chamber was removed from the transfer container. Before opening the sample chamber, a gas sample of the sampler headspace was taken via one of two septa-ports in the upper section of sample chamber.

After the headspace sample, the sample chamber was opened and the liquid poured off. Since the sample chamber remained sealed from the time the sample was obtained until the sample chamber was opened in the hot cell, the sample blank was prepared in a 500-milliliter PFA (Teflon) bottle inside the hot cell upon receipt of the sample chamber. Each trip blank was analyzed to determine possible contamination from container preparation, handling, or storage.

Four 20-milliliter bottles of raw sample were sent for volatile organics analysis and the rest was poured through a 140-mesh screen to collect coarse solids. The slurry remaining in the sample chamber was rinsed with $0.1 \mathrm{M}$ Nitric Acid $\left(\mathrm{HNO}_{3}\right)$ to collect residual solids and then poured through a 140-mesh screen. The coarse solids were rinsed off the 140-mesh screen with $0.1 \mathrm{M} \mathrm{HNO}_{3}$ and allowed to settle. The $0.1 \mathrm{M} \mathrm{HNO}_{3}$ was poured off after 24 hours and the coarse solids fraction was then air-dried in preparation for analysis.

Following the 140-mesh screening, the liquid was poured into 50-milliliter test tubes and centrifuged to recover the fine solids. The centrifuge supernate was partitioned and iced in preparation for semivolatile organic analyses, or poured into aliquots for metals or radiochemistry analyses. The fine solids were transferred to beakers with $0.1 \mathrm{M} \mathrm{HNO}_{3}$ and a scoopula. Settling of the fine solids fractions occurred during the next 72-96 hours, at which time the $0.1 \underline{\mathrm{M}} \mathrm{HNO}_{3}$ was poured off. The fine solids fraction was then air-dried in preparation for analysis.

After both coarse and fine solids fractions dried, the physical properties of each fraction were measured. Then, the fractions were recombined to maximize the data obtained from the limited solids mass. These activities and the subsequent analyses were performed in accordance with PLN-407, Quality Assurance Project Plan for the Analysis of Environmental Samples, and MCP-2004, Sample Management in the Analytical Chemistry Laboratory.

4.2.2.3 Liquid Sample Results. Although the primary purpose of sampling Tank WM-188 was to demonstrate the technology, it was recognized that the data would be invaluable for other initiatives. To that end, RCRA protocol was used as much as practical to standardize the information. The table below summarizes the liquid analyses required by the Sample Analysis Plan (SAP), average results, and standard deviation of the samples: 
Table 2. Liquid Sample Results.

\begin{tabular}{|c|c|c|c|c|c|}
\hline Analyte & Average & $\begin{array}{l}\text { Standard } \\
\text { Deviation }\end{array}$ & Analyte & Average & $\begin{array}{l}\text { Standard } \\
\text { Deviation } \\
\end{array}$ \\
\hline \multicolumn{3}{|c|}{ Total Metals $(\mu \mathrm{g} / \mathrm{ml})$} & \multicolumn{3}{|l|}{ Radionuclides (dps/ml) } \\
\hline Silver & $<4.83 \mathrm{E}-02$ & NA & Am-241 & $2.68 \mathrm{E}+03$ & $2.18 \mathrm{E}+02$ \\
\hline Arsenic & $8.55 \mathrm{E}+00$ & $2.95 \mathrm{E}+00$ & Am-242 & Not analyzed & NA \\
\hline Barium & $1.84 \mathrm{E}+01$ & $2.23 \mathrm{E}+00$ & $\mathrm{~Np}-237$ & $2.54 \mathrm{E}+01$ & $8.89 \mathrm{E}-01$ \\
\hline Beryllium & 4.15E-02 & $3.98 \mathrm{E}-03$ & $\mathrm{I}-129$ & $<1.01 \mathrm{E}+03$ & NA \\
\hline Cadmium & $1.16 \mathrm{E}+03$ & $3.53 \mathrm{E}+01$ & Cs-134 & $2.65 \mathrm{E}+04$ & $6.53 \mathrm{E}+02$ \\
\hline Chromium & $6.86 \mathrm{E}+02$ & $4.32 \mathrm{E}+01$ & Cs-137 & $1.25 \mathrm{E}+07$ & $3.93 \mathrm{E}+05$ \\
\hline Mercury & $1.26 \mathrm{E}+03$ & $7.18 \mathrm{E}+01$ & $\mathrm{C}-14$ & $6.99 \mathrm{E}+03$ & $8.52 \mathrm{E}+03$ \\
\hline Nickel & $3.31 \mathrm{E}+02$ & $9.64 \mathrm{E}+00$ & Sr-90 & $9.03 \mathrm{E}+06$ & $1.07 \mathrm{E}+06$ \\
\hline Lead & $2.20 \mathrm{E}+02$ & $6.07 \mathrm{E}+00$ & Eu-154 & $5.32 \mathrm{E}+04$ & $6.19 \mathrm{E}+03$ \\
\hline Selenium & $<6.53 \mathrm{E}-01$ & NA & Eu-155 & $2.03 \mathrm{E}+04$ & $2.33 \mathrm{E}+03$ \\
\hline Antimony & $2.85 \mathrm{E}+00$ & $7.26 \mathrm{E}-01$ & $\mathrm{Co}-60$ & $9.67 \mathrm{E}+03$ & $7.78 \mathrm{E}+02$ \\
\hline Thallium & $<7.81 \mathrm{E}-01$ & NA & Tc-99 & $6.55 \mathrm{E}+03$ & $2.07 \mathrm{E}+03$ \\
\hline Vanadium & $1.04 \mathrm{E}+00$ & $1.37 \mathrm{E}-01$ & $\mathrm{Pu}-238$ & $4.82 \mathrm{E}+04$ & $1.33 \mathrm{E}+03$ \\
\hline Zinc & $6.55 \mathrm{E}+01$ & $1.51 \mathrm{E}+00$ & $\mathrm{Pu}-239$ & $5.22 \mathrm{E}+03$ & $1.60 \mathrm{E}+02$ \\
\hline Aluminum & $1.94 \mathrm{E}+04$ & $4.82 \mathrm{E}+02$ & $\mathrm{U}-234$ & $<1.41 \mathrm{E}+01$ & NA \\
\hline Ruthenium & $2.48 \mathrm{E}+01$ & $1.10 \mathrm{E}+01$ & $\mathrm{U}-235$ & $8.88 \mathrm{E}-01$ & $0.00 \mathrm{E}+00$ \\
\hline Molybdenum & $6.18 \mathrm{E}+01$ & $1.13 \mathrm{E}+00$ & $\mathrm{U}-236$ & 4.81E-01 & NA \\
\hline Silicon & Not analyzed & NA & $\mathrm{U}-238$ & $1.21 \mathrm{E}+00$ & $1.85 \mathrm{E}-02$ \\
\hline Zirconium & $2.72 \mathrm{E}+03$ & $5.98 \mathrm{E}+01$ & \multicolumn{3}{|c|}{ Organic Compounds $(\mu \mathrm{g} / \mathrm{ml})$} \\
\hline Niobium & $3.62 \mathrm{E}+00$ & $1.79 \mathrm{E}-01$ & Acetone & $5.03 \mathrm{E}-02$ & $2.49 \mathrm{E}-02$ \\
\hline Boron & $4.57 \mathrm{E}+02$ & $6.93 \mathrm{E}+00$ & Benzene & $<4.00 \mathrm{E}-03$ & NA \\
\hline Iron & $2.99 \mathrm{E}+03$ & $2.25 \mathrm{E}+02$ & 2-Butanone & $1.27 \mathrm{E}-02$ & $5.03 \mathrm{E}-03$ \\
\hline Manganese & $7.08 \mathrm{E}+02$ & $8.20 \mathrm{E}+00$ & Carbon Disulfide & $<5.00 \mathrm{E}-03$ & NA \\
\hline Phosphorus & $1.72 \mathrm{E}+00$ & $6.56 \mathrm{E}-02$ & Carbon Tetrachloride & $<8.00 \mathrm{E}-03$ & NA \\
\hline Calcium & $5.88 \mathrm{E}+03$ & $1.97 \mathrm{E}+02$ & Methyl Isobutyl Ketone & $<1.50 \mathrm{E}-02$ & NA \\
\hline Cesium & $8.78 \mathrm{E}+00$ & $1.65 \mathrm{E}+00$ & Phenol & $<2.5 \mathrm{E}-02$ & NA \\
\hline Cobalt & $5.39 \mathrm{E}+00$ & $2.87 \mathrm{E}-01$ & Pyridine & $<2.5 \mathrm{E}-02$ & NA \\
\hline \multicolumn{3}{|l|}{ Other } & Toluene & $<5.00 \mathrm{E}-03$ & NA \\
\hline Fluoride $(\mu \mathrm{g} / \mathrm{ml})$ & $3.83 \mathrm{E}+03$ & $7.26 \mathrm{E}+01$ & 1,1,1-Trichloroethane & $<4.00 \mathrm{E}-03$ & NA \\
\hline $\mathrm{PO}_{4}(\underline{\mathrm{M}})$ & Not Analyzed & NA & Xylene (m \& p) & $<2.60 \mathrm{E}-02$ & NA \\
\hline Specific Gravity & $1.28 \mathrm{E}+00$ & $3.12 \mathrm{E}-03$ & Xylene (o) & $<1.40 \mathrm{E}-02$ & NA \\
\hline Acidity $(\underline{\mathrm{M}})$ & $2.40 \mathrm{E}+00$ & $2.43 \mathrm{E}-02$ & Tributyl phosphate & $<2.5 \mathrm{E}-02$ & NA \\
\hline Chloride $(\mu \mathrm{g} / \mathrm{ml})$ & $4.24 \mathrm{E}+02$ & $2.01 \mathrm{E}+01$ & TOC & $1.54 \mathrm{E}+02$ & $1.59 \mathrm{E}+01$ \\
\hline
\end{tabular}

The standard deviation could not be calculated for any analyte for which all results were less than the Method Detection Limit (MDL), or for any analyte that had only one numerical result. For those analytes that had some results above and below the MDL, the results below the MDL were set equal to the MDL when calculating the average. The results reported as less than the MDL were not used when the standard deviation was calculated. PCBs were not analyzed because there was no organic layer on the heel for the PCBs to reside in. No results were obtained for three other analytes, as indicated in the table, due to method or equipment problems. 
One additional analyte, chlorides, was inadvertently omitted from the SAP. Analytical personnel recognized the omission and performed the analysis, for which results are included in the table. All analyses were performed at INTEC, with the exception of Carbon-14, which was analyzed at the Test Reactor Area (TRA) because the analysis can not be performed in the relatively high radiation fields at the RAL. Also of interest are the settled and centrifuged bulk results. Although the solids are definitely flocculent, it is not possible for them to be lighter than the solution and still settle to the bottom (compare the specific gravity of 1.28 from the liquids analysis). The apparent discrepancy is attributed to the small solids mass and the relatively large measuring apparati required for remote handling in the analytical hot cell.

Tier II analytical reports were prepared for all of the liquid analyses, and the percent recovery and precision were calculated as part of these reports to comply with the SAP. The SAP also requires computation of the samples' completeness as a data quality indicator. The completeness of the liquid analyses was $95.3 \%$, as compared to the SAP target of $90 \%$ completeness.

4.2.2.4 Solids Sample Results. The solids were medium-to-light gray in color with an earthy luster. Approximately 64 grams of solids were required to perform all of the analyses listed in the SAP. After drying, only 13.8 grams were collected from all four samples as indicated in the table below.

Table 3. Solid Sample Masses.

\begin{tabular}{||c|c|c|c||}
\hline \hline Sample & Coarse solids $(\mathrm{gm})^{\mathrm{a}}$ & ${\text { Fine solids }(\mathrm{gm})^{\mathrm{a}}}$ & Total solids (gm) $^{\text {Tol||}}$ \\
\hline \hline $1(335 \mathrm{~mL})$ & 0.455 & 1.896 & 2.351 \\
\hline $2(686 \mathrm{ml})$ & 0.376 & 4.519 & 4.895 \\
\hline $3(684 \mathrm{ml})$ & 1.681 & 4.173 & 5.854 \\
\hline $4(591 \mathrm{ml})$ & 0.033 & 0.642 & 0.675 \\
\hline \hline \multicolumn{2}{|l|}{} & $\mathbf{1 3 . 7 7 5}$ \\
\hline
\end{tabular}

a. Coarse solids are the solids caught on the 140-mesh (107-micron) screen. Fine solids passed through.

Less than $23 \%$ of the solids, averaged from all of the samples, had an effective diameter greater than 107 microns. When evaluating the data, it is important to remember that consistency in the sampler's performance, the sample collection method, and the local conditions at the jet suction greatly influence the results. On a mass-per-unit-volume basis, Samples \#1 and \#2 agree within 2\%, Samples \#2 and \#3 agree within 17\%, and Sample \#4 shows large variation from all of the other samples. Generally, the following conclusions can be drawn that explain some of the differences:

1. The close agreement of solids-to-liquids ratio between Sample \#1 and Samples \#2 and \#3 indicates that solids were drawn into the sampler at about the same ratio of solids-to-liquids, regardless of the sample collection method. This supports the conclusion that the solids are very flocculent, because heavier solids would not have flocked into the extra liquid being drawn into the sample chamber during Samples\#2 and \#3.

2. The $17 \%$ mass difference between Samples \#2 and \#3, attributed mainly to variation in sampler performance, is consistent with sample variations observed in laboratory testing of the sampler. Samples \#2 and \#3 were taken approximately 14 feet apart, indicating that the solids distribution is generally consistent across the tank bottom. 
3. The jet suction's localized effect is the removal of solids in an area of approximately 18 to 24 inches diameter around the suction. Based on the sample and the visual inspection, the localized reduction in solids is estimated at less than $2 \%$ of the tank bottom's total area. Assuming that the solids distribution is uniform across the tank, consistent with solids mass from Samples \#1, \#2, and \#3, is conservative with respect to estimating the risk in the heel.

After the solids were dried and weighed, they were re-hydrated and their volume increased substantially. Although not directly measured, the rehydrated volume was estimated at 2.5 to 3 times the dry volume. The percent moisture measured in the solids ranged from 55 to 59\% in Samples \#1, \#2 and \#3, as shown below.

Table 4. Percent Moisture in Solids Samples.

\begin{tabular}{||c|c|c|c||}
\hline \hline \multicolumn{4}{|c|}{ Percent Moisture } \\
\hline \hline Sample \#1 & Sample \#2 & Sample \#3 & Sample \#4 \\
\hline \hline $59.08 \%$ & $55.17 \%$ & $56.80 \%$ & $84.63 \%$ \\
\hline
\end{tabular}

Analysis of Sample \#4 indicated a higher moisture content, but because of the size of the sample less than one gram - and notable moisture observed in the sample when the wet weight was measured, the result is considered nonrepresentative.

Closer agreement between samples was observed in the solids chemical properties than in the physical properties. The table below summarizes the solids analyses required by the Sample Analysis Plan (SAP), average results, and standard deviation (where applicable) of the samples:

The standard deviation could not be calculated for any analyte that had all results below the Method Detection Limit (MDL), or for any analyte that had only one numerical result. For those analytes that had results above and below the MDL, the results below the MDL were set equal to the MDL when calculating the average. The results reported as less than the MDL were not used when the standard deviation was calculated. No results were obtained for eight analytes, as indicated in the table, due to inadequate mass, or method or equipment problems. No analysis for C-14 was performed on the solids because the required fusion was performed at a temperature high enough to alter the results.

The hold time (14 days) for volatile organics was exceeded because the analysis was performed on a solids composite, and the length of time between Samples \#1 and \#4 was 15 days. Inadequate solids mass also caused protocol deviations in the PCB analysis. Tier II analytical reports were prepared for all of the solids analyses, and the percent recovery and precision were calculated as part of these reports to comply with the SAP.

The SAP also requires computation of the samples' completeness as a data quality indicator. The completeness of the solids analyses was $89.9 \%$, as compared to the SAP target of $90 \%$ completeness. Difficulty completing all of the desired solids analyses was recognized early in the sampling effort, and was a major reason for taking the fourth sample. A fifth sample was not taken because the sample volume safety limit at the RAL was being approached, and because of the high cost of analysis. Total combined analytical costs — including method development, SAP review, and laboratory preparations of the first four samples were between 250,000 and $\$ 260,000$. 
Table 5. Solids Sample Results.

\begin{tabular}{|c|c|c|c|c|c|}
\hline Analyte & Average & $\begin{array}{l}\text { Standard } \\
\text { Deviation } \\
\end{array}$ & Analyte & Average & $\begin{array}{l}\text { Standard } \\
\text { Deviation } \\
\end{array}$ \\
\hline \multicolumn{3}{|l|}{ Physical Properties } & \multicolumn{3}{|l|}{ Radionuclides (dps/gm) } \\
\hline UDS $(\mathrm{g} / \mathrm{L})$ & $7.57 \mathrm{E}+00^{\mathrm{a}}$ & 8.57E-01 & Am-241 & $7.79 \mathrm{E}+03$ & $2.09 \mathrm{E}+03$ \\
\hline Particle Size/Density (microns) & $23 \%>107$ & NA & Am-242 & Not analyzed & NA \\
\hline Bulk Density-settled (g/cc) & 0.85 & NA & $\mathrm{Np}-237$ & $1.05 \mathrm{E}+02$ & $5.97 \mathrm{E}+01$ \\
\hline Bulk Density-centrifuged $(\mathrm{g} / \mathrm{cc})$ & 1.22 & $\mathrm{NA}$ & $\mathrm{I}-129$ & $<5.65 \mathrm{E}+04$ & $\mathrm{NA}$ \\
\hline Settling Velocity & Not analyzed & $\mathrm{NA}$ & Cs-134 & $2.95 \mathrm{E}+05$ & $6.21 \mathrm{E}+04$ \\
\hline \multicolumn{3}{|l|}{ Other } & Cs-137 & $9.02 \mathrm{E}+07$ & $2.89 \mathrm{E}+07$ \\
\hline Fluoride (ug/ml) & $3.10 \mathrm{E}+01$ & NA & $\mathrm{C}-14$ & Not analyzed & NA \\
\hline $\mathrm{Cl}^{-}(\mathrm{mg} / \mathrm{kg})^{3}$ & Not analyzed & NA & $\mathrm{Sr}-90$ & $2.02 \mathrm{E}+08$ & $8.51 \mathrm{E}+07$ \\
\hline PCBs $(\mathrm{mg} / \mathrm{kg})$ & $<2.0 \mathrm{E}+01$ & NA & Eu-154 & $2.01 \mathrm{E}+04$ & NA \\
\hline \multicolumn{3}{|l|}{ Total Metals (mg/kg) } & Eu-155 & Not analyzed & NA \\
\hline Silver & $9.11 \mathrm{E}+00$ & $5.68 \mathrm{E}+00$ & Co-60 & $2.33 \mathrm{E}+04$ & NA \\
\hline Arsenic & $3.51 \mathrm{E}+02$ & $1.62 \mathrm{E}+01$ & Tc-99 & $1.66 \mathrm{E}+05$ & $2.90 \mathrm{E}+04$ \\
\hline Barium & $1.25 \mathrm{E}+04$ & $7.58 \mathrm{E}+03$ & $\mathrm{Pu}-238$ & $2.80 \mathrm{E}+05$ & $4.99 \mathrm{E}+04$ \\
\hline Beryllium & $<2.27 \mathrm{E}-01$ & NA & $\mathrm{Pu}-239$ & $1.59 \mathrm{E}+04$ & $3.60 \mathrm{E}+03$ \\
\hline Cadmium & $1.19 \mathrm{E}+03$ & $2.58 \mathrm{E}+02$ & $\mathrm{U}-234$ & $<7.77 \mathrm{E}+02$ & NA \\
\hline Chromium & $1.34 \mathrm{E}+03$ & $1.81 \mathrm{E}+02$ & $\mathrm{U}-235$ & $7.28 \mathrm{E}+00$ & $1.19 \mathrm{E}+00$ \\
\hline Mercury & $1.57 \mathrm{E}+03$ & $4.58 \mathrm{E}+02$ & $\mathrm{U}-236$ & $<8.14 \mathrm{E}+00$ & NA \\
\hline Nickel & $4.27 \mathrm{E}+02$ & $1.12 \mathrm{E}+02$ & $\mathrm{U}-238$ & $4.38 \mathrm{E}+00$ & $1.68 \mathrm{E}+00$ \\
\hline Lead & $6.47 \mathrm{E}+02$ & $1.35 \mathrm{E}+02$ & $\mathrm{Nb} 94$ & $1.36 \mathrm{E}+05$ & $1.08 \mathrm{E}+05$ \\
\hline Selenium & $<1.72 \mathrm{E}+03$ & $\mathrm{NA}$ & $\mathrm{Sb} 125$ & $4.14 \mathrm{E}+05$ & NA \\
\hline Antimony & $<3.36 \mathrm{E}+01$ & $\mathrm{NA}$ & \multicolumn{3}{|c|}{ Organic Compounds $(\mathrm{mg} / \mathrm{kg})$} \\
\hline Thallium & $<7.83 \mathrm{E}+02$ & NA & Acetone & $6.80 \mathrm{E}+02$ & NA \\
\hline Vanadium & $6.10 \mathrm{E}+00$ & NA & Benzene & $<5.7 \mathrm{E}+01$ & $\mathrm{NA}$ \\
\hline Zinc & $1.26 \mathrm{E}+02$ & $4.25 \mathrm{E}+01$ & 2-Butanone & $<7.2 \mathrm{E}+01$ & NA \\
\hline Aluminum & $3.54 \mathrm{E}+04$ & $2.43 \mathrm{E}+03$ & Carbon Disulfide & $<2.3 \mathrm{E}+01$ & $\mathrm{NA}$ \\
\hline Ruthenium & $<3.13 \mathrm{E}+02$ & $\mathrm{NA}$ & Carbon Tetrachloride & $<3.6 \mathrm{E}+01$ & NA \\
\hline Molybdenum & $2.77 \mathrm{E}+03$ & $4.59 \mathrm{E}+02$ & Methyl Isobutyl Ketone & $<6.1 \mathrm{E}+01$ & NA \\
\hline Silicon & Not analyzed & NA & Phenol & $<3.1 \mathrm{E}+00$ & NA \\
\hline Zirconium & $7.06 \mathrm{E}+04$ & $3.01 \mathrm{E}+04$ & Pyridine & $<3.1 \mathrm{E}+00$ & NA \\
\hline Niobium & $5.37 \mathrm{E}+03$ & $4.11 \mathrm{E}+03$ & Toluene & $<6.4 \mathrm{E}+01$ & $\mathrm{NA}$ \\
\hline Boron & $<4.84 \mathrm{E}+02$ & NA & 1,1,1-Trichloroethane & $<4.8 \mathrm{E}+01$ & NA \\
\hline Iron & $5.77 \mathrm{E}+03$ & $6.98 \mathrm{E}+02$ & Xylene (m \& p) & $<1.09 \mathrm{E}+02$ & NA \\
\hline Manganese & $7.58 \mathrm{E}+02$ & $2.92 \mathrm{E}+02$ & Xylene (o) & $<5.6 \mathrm{E}+01$ & NA \\
\hline Phosphorus & $1.77 \mathrm{E}+04$ & $1.30 \mathrm{E}+04$ & TBP & $<3.1 \mathrm{E}+00$ & NA \\
\hline Calcium & $5.63 \mathrm{E}+03$ & $2.10 \mathrm{E}+03$ & TOC & Not analyzed & $\mathrm{NA}$ \\
\hline Cesium & $<1.28 \mathrm{E}+02$ & NA & & & \\
\hline Cobalt & $8.67 \mathrm{E}+00$ & $6.64 \mathrm{E}-01$ & & & \\
\hline
\end{tabular}

a. The UDS value and standard deviation were calculated using Samples 1, 2, and 3, because Sample 4 is considered nonrepresentative. 


\subsubsection{Additional Heel Evaluations}

Beyond the analyses described in the SAP, the samples were evaluated and data interpreted in several ways to provide a better understanding of the tank heel. The observations should prove useful in closing the tanks and developing flow sheets and waste forms for the heel material.

4.2.3.1 Stratification-Comparison to Previous Samples. Portions of the WM-188 LDUA sample results were compared to two RCRA samples taken from WM-188 via the New Waste Calcining Facility (NWCF), enabling an evaluation of the vertical variation in the tank solution. Although the samples taken via NWCF were steam jetted fromWM-188 to NWCF, resulting in a 5 to $10 \%$ dilution of the samples, the same protocol was applied to both types of samples. Since liquid metals results were compared, the temperature effects of the steam-jet (approximately $60^{\circ} \mathrm{C}$ ) were negligible.

Table 6. Comparison of Liquid Metals Results to Previous Samples.

\begin{tabular}{|c|c|c|c|c|}
\hline ANALYTE & $\begin{array}{c}\text { \#1 NWCF RCRA } \\
\text { sample of WM-188 } \\
\text { VOL }_{188}=37,680 \mathrm{gal} \\
\end{array}$ & $\begin{array}{c}\text { \#2 NWCF RCRA } \\
\text { sample of WM-188 } \\
\text { VOL }_{188}=17,580 \text { gal } \\
\end{array}$ & \begin{tabular}{|c|} 
LDUA WM-188 \\
$\begin{array}{c}\text { Liquid Sample } \\
\text { Averages }\end{array}$ \\
\end{tabular} & $\begin{array}{l}\text { NWCF Sample average } \\
\text { as \% of LDUA average }\end{array}$ \\
\hline Antimony $(\mu \mathrm{g} / \mathrm{L})$ & $<2.450 \mathrm{E}+03$ & $<2.450 \mathrm{E}+03$ & $2.85 \mathrm{E}+03$ & $\mathrm{~N} / \mathrm{A}$ \\
\hline Arsenic $(\mu \mathrm{g} / \mathrm{L})$ & $3.89 \mathrm{E}+04$ & $5.53 \mathrm{E}+04$ & $8.55 \mathrm{E}+03$ & 551 \\
\hline Barium $(\mu \mathrm{g} / \mathrm{L})$ & $1.24 \mathrm{E}+04$ & $1.45 \mathrm{E}+04$ & $1.84 \mathrm{E}+04$ & 73 \\
\hline Beryllium $(\mu \mathrm{g} / \mathrm{L})$ & $<7.91 \mathrm{E}+02$ & $<7.91 \mathrm{E}+02$ & $4.15 \mathrm{E}+01$ & N/A \\
\hline Cadmium $(\mu \mathrm{g} / \mathrm{L})$ & $6.85 \mathrm{E}+05$ & $1.46 \mathrm{E}+06$ & $1.16 \mathrm{E}+06$ & 93 \\
\hline Chromium $(\mu \mathrm{g} / \mathrm{L})$ & $6.85 \mathrm{E}+05$ & $9.00 \mathrm{E}+05$ & $6.86 \mathrm{E}+05$ & 115 \\
\hline Lead $(\mu \mathrm{g} / \mathrm{L})$ & $1.80 \mathrm{E}+05$ & $2.27 \mathrm{E}+05$ & $2.20 \mathrm{E}+05$ & 93 \\
\hline Nickel $(\mu \mathrm{g} / \mathrm{L})$ & $2.52 \mathrm{E}+05$ & $2.84 \mathrm{E}+05$ & $3.31 \mathrm{E}+05$ & 81 \\
\hline Selenium $(\mu \mathrm{g} / \mathrm{L})$ & $<6.280 \mathrm{E}+03$ & $<6.280 \mathrm{E}+03$ & $<6.531 \mathrm{E}+02$ & N/A \\
\hline Silver $(\mu \mathrm{g} / \mathrm{L})$ & $4.65 \mathrm{E}+03$ & $5.51 \mathrm{E}+03$ & $<4.83 \mathrm{E}+01$ & N/A \\
\hline Thallium $(\mu \mathrm{g} / \mathrm{L})$ & $<6.780 \mathrm{E}+03$ & $<6.780 \mathrm{E}+03$ & $<7.812 \mathrm{E}+02$ & N/A \\
\hline Vanadium $(\mu \mathrm{g} / \mathrm{L})$ & $1.21 \mathrm{E}+03$ & $1.75 \mathrm{E}+03$ & $1.04 \mathrm{E}+03$ & 142 \\
\hline Zinc $(\mu \mathrm{g} / \mathrm{L})$ & $4.85 \mathrm{E}+04$ & $6.88 \mathrm{E}+04$ & $6.55 \mathrm{E}+04$ & 90 \\
\hline Mercury $(\mu \mathrm{g} / \mathrm{L})$ & $1.40 \mathrm{E}+06$ & $1.66 \mathrm{E}+06$ & $1.24 \mathrm{E}+06$ & 123 \\
\hline Acid N & $2.57 \mathrm{E}+00$ & $2.53 \mathrm{E}+00$ & $2.40 \mathrm{E}+00$ & 106 \\
\hline Fluorides (mg/L) & $9.97 \mathrm{E}+03$ & $7.31 \mathrm{E}+03$ & $3.83 \mathrm{E}+03$ & 226 \\
\hline
\end{tabular}

NWCF RCRA samples were taken when the volume in WM-188 was 37,680 gallons and 17,580 gallons, respectively. The far right-hand column of the table expresses the NWCF sample results as a percentage of the LDUA average results. There is close agreement in the values with two exceptions-Arsenic and Fluorides.

Fluorides are concentrated in the NWCF scrub system and recycled to the tank farm through the Blend and Hold Cell, where the NWCF samples originated. Therefore, it is reasonable to assume the higher NWCF Fluorides resulted from scrub solution in the Blend and Hold Tanks. As yet, there is no conclusive explanation for higher Arsenic results in the NWCF samples, although it is known that the 
Arsenic analysis is strongly interfered by Aluminum. Ignoring the Fluoride and Arsenic results because they are suspect, there is no indication that chemical content varies with respect to tank volume.

Reworded, no evidence of stratification exists for WM-188. The high NWCF Arsenic results warrant further investigation, but are beyond the scope of this report.

4.2.3.2 Comparison of Solids and Liquid Sample Results. Extra handling and the fusions required to analyze the solids add some variability to a comparison of the solids and liquids. A qualitative comparison is still valuable, and the following table expresses the radionuclide and metals results of the solids as a percentage of the same analytes in the liquid. This allows a qualitative evaluation of the relative risk of each phase of the heel.

Table 7. Comparison of Solids and Liquids Sample Results.

\begin{tabular}{|c|c|c|c|c|c|c|c|}
\hline Analyte & $\begin{array}{l}\text { Solids Averages } \\
(\mathrm{mg} / \mathrm{kg})\end{array}$ & \begin{tabular}{|l|} 
Liquid \\
Average $(\mathrm{mg} / \mathrm{kg})$
\end{tabular} & $\begin{array}{l}\text { Metals Ratio } \\
\text { Solids:Liquids }\end{array}$ & Radionuclide & $\begin{array}{l}\text { Solids } \\
\text { Average } \\
\text { (dps/gm) }\end{array}$ & $\begin{array}{l}\text { Liquid Average } \\
\text { (dps/gm) }\end{array}$ & \begin{tabular}{|l} 
Radionuclide \\
Ratio \\
Solids:Liquids
\end{tabular} \\
\hline Aluminum & $3.54 \mathrm{E}+04$ & $1.51 \mathrm{E}+04$ & 2.3 & Co 60 & $2.33 \mathrm{E}+04$ & $7.54 \mathrm{E}+03$ & 3.1 \\
\hline Arsenic & $3.51 \mathrm{E}+02$ & $6.67 \mathrm{E}+00$ & 52.6 & Sr 90 & $2.02 \mathrm{E}+08$ & $7.04 \mathrm{E}+06$ & 28.7 \\
\hline Barium & $1.25 \mathrm{E}+04$ & $1.44 \mathrm{E}+01$ & 874 & Tc 99 & $1.66 \mathrm{E}+05$ & $5.11 \mathrm{E}+03$ & 32.5 \\
\hline Cadmium & $1.19 \mathrm{E}+03$ & $9.02 \mathrm{E}+02$ & 1.3 & Cs 134 & $2.95 \mathrm{E}+05$ & $2.07 \mathrm{E}+04$ & 14.3 \\
\hline Calcium & $5.63 \mathrm{E}+03$ & $4.58 \mathrm{E}+03$ & 1.2 & Cs 137 & $9.02 \mathrm{E}+07$ & $9.77 \mathrm{E}+06$ & 9.2 \\
\hline Chromium & $1.34 \mathrm{E}+03$ & $5.35 \mathrm{E}+02$ & 2.5 & Eu 154 & $2.01 \mathrm{E}+04$ & $4.15 \mathrm{E}+04$ & 0.5 \\
\hline Cobalt & $8.67 \mathrm{E}+00$ & $4.21 \mathrm{E}+00$ & 2.1 & U 235 & 7.28E+00 & 6.93E-01 & 10.5 \\
\hline Iron & $5.77 \mathrm{E}+03$ & $2.34 \mathrm{E}+03$ & 2.5 & U 238 & $4.38 \mathrm{E}+00$ & 9.45E-01 & 4.6 \\
\hline Lead & $6.47 \mathrm{E}+02$ & $1.71 \mathrm{E}+02$ & 3.8 & $\mathrm{~Np} 237$ & $1.05 \mathrm{E}+02$ & $1.98 \mathrm{E}+01$ & 5.3 \\
\hline Manganese & $7.58 \mathrm{E}+02$ & $5.52 \mathrm{E}+02$ & 1.4 & $\mathrm{Pu} 238$ & $2.80 \mathrm{E}+05$ & $3.76 \mathrm{E}+04$ & 7.4 \\
\hline Nickel & $4.27 \mathrm{E}+02$ & $2.58 \mathrm{E}+02$ & 1.7 & $\mathrm{Pu} 239$ & $1.59 \mathrm{E}+04$ & $4.07 \mathrm{E}+03$ & 3.9 \\
\hline Vanadium & $6.10 \mathrm{E}+00$ & 8.13E-01 & 7.5 & Am 241 & 7.79E+03 & $2.09 \mathrm{E}+03$ & 3.7 \\
\hline Zinc & $1.26 \mathrm{E}+02$ & $5.11 \mathrm{E}+01$ & 2.5 & Solids:Liquid & (Composite) & & 17.3 \\
\hline Mercury & $1.57 \mathrm{E}+03$ & $9.79 \mathrm{E}+02$ & 1.6 & & & & \\
\hline Molybdenum & $2.77 \mathrm{E}+03$ & $4.82 \mathrm{E}+01$ & 57.5 & & & & \\
\hline Zirconium & $7.06 \mathrm{E}+04$ & $2.12 \mathrm{E}+03$ & 33.3 & & & & \\
\hline Niobium & $5.37 \mathrm{E}+03$ & $2.82 \mathrm{E}+00$ & 1901 & & & & \\
\hline Phosphorus & $1.77 \mathrm{E}+04$ & $1.34 \mathrm{E}+00$ & 13245 & & & & \\
\hline
\end{tabular}

No effort was made to compare the solid and liquid organics because most results were below the detection limit. Although the ratio for each tabulated analyte varies, it is obvious that the solids contain significantly more metals and radionuclides per gram of material. When the total curie content was compared, the solids contained approximately seventeen times the curies-per-gram content of the liquid. Detailed mass and radionuclide balances of the solids and liquids were not performed, so this comparison should be considered just a general indicator.

4.2.3.3 Evaluation of Solids Flocculence and Washing. Although settling velocity was not measured, observations during the solids handling process provide a qualitative gauge of solids flocculence. The fraction of solids above 107 microns in diameter - $23 \%$ by mass - was rinsed and allowed to settle before the final pour off. Settling occurred within 24 hours. The fraction of solids smaller than 107 microns in diameter $-77 \%$ by mass - was also rinsed and allowed to settle. Complete settling of the visible solids did not occur for 72 to 96 hours. The conclusion drawn from this observation is that although a value for settling velocity was not obtained, a significant portion of the solids could be 
steam-jetted or pumped from the tank if a mechanism for flocking the solids into the liquid is introduced during heel removal.

To provide a qualitative evaluation of how hard it will be to wash interstitial liquids from the solids, a solids remnant was washed an agitated in 0.1 Molar $\mathrm{HNO}_{3}$, then centrifuged. The solids remnant sat overnight in 0.1 Molar $\mathrm{HNO}_{3}$ solution, and then the centrifuging process was repeated. A gamma scan was performed on the solids remnant and the results were compared to the gamma scan data from the first three sets of analyses. Essentially no change was detected in the data - all of the results from the gamma scan of washed solids fell within the range (in fact one result increased) of analytical error of the original three analyses. The conclusion drawn from the results is that removal of the interstitial liquids will take development of more effective methods than standard washing techniques.

4.2.3.4 Headspace Sampling. Sampling of the sample chamber headspace proved unproductive. An experimental apparatus was constructed to sample and analyze the headspace, but the laboratory does not have the capability to spike air samples so MS/MSD, LCS, MDLs, surrogates, and internal standards were not used. The headspace sample volume was estimated, as the apparatus could not accurately measure the sample volume. Hold times were exceeded, and some plastic laboratory equipment was used. In general, Acetone, Benzene and trace amounts of other organics were detected, but the Acetone and Benzene levels in the cell blank exceeded the levels in the sample. The results from this test are not reliable and if future efforts indicate headspace sampling is warranted, considerable effort will be required to develop a better headspace sample scheme. 


\section{CONCLUSION}

In general, the LDUA deployment in Tank WM-188 was very successful. Information vital to the High-Level Waste and Facility Disposition EIS and the INTEC Tank Closure Project was obtained. The technology was demonstrated, and enough information gained about the equipment to determine whether each piece of equipment functioned adequately, needed improvements, or should be abandoned in lieu of other more promising technology. Flowsheet and waste form development will be greatly improved due to the sample data obtained. The INTEC Incidental Waste Ruling Project is using the analytical data as starting point for an incidental waste determination. Finally, results from the visual inspection were incorporated in a report on tank condition to the State of Idaho, and were further incorporated in a modification to the report in November 1999. Both the report and the modification are required by the Third Modification to the Notice of Noncompliance Consent Order.

\section{$5.1 \quad$ Lessons Learned}

The following lessons learned are broken into four areas. They were extracted from input from Projects, Operations, Remote Inspection personnel, the Analytical Laboratory, and others, but are not allinclusive. As such, their relative importance is the opinion of the author, and not all of the available information is listed here. Individuals seeking specific information from the LDUA development and deployment should look beyond this report to weigh every success and failure.

\subsubsection{Project Lessons Learned}

Purchase of proprietary software should either meet all specifications prior to purchase or the purchase should be conditioned for set-price servicing during use.

Technology development projects with new or state of the art equipment should be initiated with large contingencies cost and schedule - built in. For this project, at least a $25 \%$ cost and schedule contingencies would have been appropriate.

Early involvement of Operations personnel in development of equipment and systems is extremely beneficial to both groups. Operations received a product better tailored for end-use and training was greatly enhanced.

\subsubsection{Operations Lessons Learned}

The LDUA can be deployed in the INTEC Tank Farm and successfully draw samples and perform video inspections. The ACFM End Effector, although successfully demonstrated, can probably not support defendable integrity evaluations of the tanks.

Although discouraged, the LDUA can be deployed in cold weather. Significant risks, such as personnel cold stress, freezing of equipment, and the increased likelihood of contamination spread, must be accepted for a cold weather deployment.

Accepting equipment at no cost is not necessarily an advantage if the equipment does not meet the requirements of the project. At best, the project has equipment with little practical use. At worst, integrating the equipment drains valuable resources.

Acceptance of readiness criteria from other sources using similar equipment in different circumstances, compromises a project's chances of success. A meticulous review of actual needs and 
requirements, without bias from other programs, will result in the correct degree of rigor. An internal review to demonstrate readiness for the INEEL LDUA deployment provided the correct degree of rigor.

\subsubsection{Sampling Lessons Learned}

Decontamination of the sample chambers at the Analytical Laboratory may not always be possible, especially if the spray system is not available (for example, in cold weather). Sampling schemes should incorporate running batches of samples related to the number of available sample chambers in the sample plan.

A program or project point of contact should be identified who can be reached at any time to direct Analytical personnel with regard to sample priorities and decisions. Written guidance alone is inadequate.

Involvement of Analytical personnel in developing sample plans and strategies based on laboratory capabilities is imperative to successful sampling. Early involvement of projects, technical development, and environmental personnel is also highly recommended. The diverse needs and capabilities of these groups merit a formal systems approach to developing sample plans.

\subsection{Recommendations}

Recommendations in this report are generally divided into three categories - equipment, sampling, and programmatic. Operations issued and implemented recommendations based on a review of the deployment within that organization. Hence, operational recommendations are not included.

\subsubsection{Equipment Recommendations}

Complete integration of the truck-mounted LDUA with the current control systems. Test new end effectors - Gripper, Eddy Current NDE, and SSTP End Effectors - with the truck-mounted arm to allow modification, if required.

Continue quantifying the effect of the sampler vacuum on organics using laboratory testing of surrogate solutions. Incorporate forthcoming EPA guidance with regard to headspace and volatile organics sampling.

Replace (or recalibrate) the radiation monitor installed on the LDUA with a lower-range instrument.

Evaluate equipment modifications, including an attachment to the capture tube, to allow more solids collection.

Complete modifications to the laser alignment system to enable quicker and more accurate laser alignment measurements of the tank risers.

Engineer improvements to the HRSVS lens carousel to improve magnification and focus capability. If improvements appear too costly $(>\$ 50,000)$, evaluate independent camera systems as an alternative. 


\subsubsection{Sampling Recommendations}

Continue investigation and development of analysis techniques to measure particle size distributions, solids settling velocity, solids chloride content, and solids C-14 activity.

Consider composites for all liquid and solids analyses except for the solids physical measurements; mass per sample, particle size distributions, and settling velocities. Homogeneity of these physical properties has not been well established because of the small solids mass. Improvements in physical measurement methods is key to this strategy.

Evaluate instituting NQA-1 or equivalent quality controls on future sample plans, as they will be used to establish baselines for closure activities.

\subsubsection{Programmatic Recommendations}

Establish tank integrity inspection requirements based on the NDE End Effector specifications versus the ACFM End Effector.

Maintain the truck-mounted arm radiologically clean until maintenance requirements can be established for the trailer-mounted arm and until current end effectors in development can be tested.

Evaluate modifying the NDE End Effector for submersion. The evaluation should incorporate reassessment of the need for submersion with regard to certifying the tank for use.

Evaluate other available inspection techniques as a backup to the NDE End Effector. Ultrasonic inspection techniques being developed for certification of Yucca Mountain waste containers appears promising. 


\section{REFERENCES}

1. Lockheed Martin Idaho Technologies Corporation, Light Duty Utility Arm Shift Supervisor Log, January - March 1999.

2. Lockheed Martin Idaho Technologies Corporation, Light Duty Utility Arm Operator Log, January through March 1999.

3. W. B. Palmer, et al., Status and Estimated Life of the 300,000-Gallon INTEC Tanks, INEEL/EXT-99-00743 (Rev 1)), November 1999.

4. Letter, C. E. Johnson to R. C. Ashby, et al., Lessons Learned Review for LDUA ProjectCEJ-08-98, November 19,1998.

5. Conversations, Cal D. Christensen, LDUA Project Technical Lead, November and

6. Letter, R. R. Chase to E. J. Ziemianski, “LDUA Deployment - RRC-07-98," dated December 21, 1998.

7. Consent Order Idaho Code Section 39-4413, Second Modification, U.S. Environmental Protections Agency, State of Idaho Department of Health and Welfare, and Department of Energy Idaho Office, August 1998.

8. Letter, E. J. Ziemianski to R. R. Chase, "Winter Deployment of the Light Duty Utility Arm (OPE-INTEC-99-002)," dated January 7, 1999.

9. Cal D. Christensen, deployment notes, "Issues Related to LDUA Cold-Weather Deployment," December 12, 1998.

10. "Light Duty Utility Arm (LDUA) February 1999 Deployment Report (WM-188)," prepared for R. R. Chase, Deputy INTEC Site Area Director by A. R. Prather and N. K. Winter, dated April 19, 1999.

11. LDUA Operator's Manual (SPAR-LDUA-HBK.056), August 1996.

12. Technical Task Description (TTP No. ID-77WT-22), “characterize INEEL Tank Farm Heels LDUA Deployment.

13. Joel R. Sanda, LDUA Operating Supervisor: memo - "LDUA Performance in WM-188," March $18,1999$.

14. SAIC Partitioning Testing \#1.

15. SAIC Partitioning Testing \#2.

16. Letter, W. J. Dirk to A. R. Prather, "Remote Corrosion Inspection of VES-WM-188 DIRK-06-99," dated March 23, 1999.

17. “ICPP Tank Farm HLLWT Visual Inspections," 1/12/94 (Video tracking number: INEEL1999-EXT-193). 
18. Sampling and Analysis Plan for the Light Duty Utility Arm Tank Farm Heel Characterization, Rev. 3; prepared by SAIC for LMITCO, INEEL, February 3, 1999, Contract No. C93-170382, TO 37.

19. LDUA Tank Farm Heel Characterization, Tier 2 analytical report, Sample logs 990210-4 and 990301-6. 